\title{
Antioxidant and anti-inflammatory effects of extracts from Maqui berry Aristotelia chilensis in human colon cancer cells
}

\author{
Carlos L. Céspedes-Acuña ${ }^{\mathrm{a}, *}$, Jianbo Xiao $^{\mathrm{b}}$, Zhao-Jun Wei $^{\mathrm{c}}$, Longsheng Chen ${ }^{\mathrm{d}}$, Jose M. Bastias ${ }^{\mathrm{e}}$, \\ José G. Avila ${ }^{\mathrm{f}}$, Julio Alarcon-Enos ${ }^{\mathrm{a}}$, Enrique Werner-Navarrete ${ }^{\mathrm{a}}$ and Isao Kubo ${ }^{\mathrm{g}}$ \\ ${ }^{a}$ Department of Basic Sciences, Research Group in Chemistry and Biotechnology of Bioactive \\ Natural Products, Faculty of Sciences, Universidad del Bio Bio, Chillan, Chile \\ ${ }^{\mathrm{b}}$ Institute of Chinese Medical Sciences, State Key Laboratory of Quality Research in Chinese Medicine, \\ University of Macau, Taipa, Macau \\ ${ }^{\mathrm{c}}$ School of Food Science and Engineering, Hefei University of Technology, Hefei, People's Republic of China \\ ${ }^{\mathrm{d}}$ Anhui Academy of Science and Technology, Hefei, P.R. China \\ e Departamento de Ingeniería en Alimentos, Grupo de Investigación Calidad, Toxicología e Inocuidad \\ Alimentaria, Facultad de Ciencias de la Salud y los Alimentos, Universidad del Bio Bio, Chillan, Chile \\ ${ }^{\mathrm{f}}$ Laboratorio de Fitoquímica, UBIPRO, FES-Iztacala, Universidad Nacional Autónoma de México, \\ Avenida de Los Barrios 1, Tlalnepantla 54090, Estado de México, México \\ ${ }^{\mathrm{g}}$ Department of Environmental Science, Policy and Management, University of California, Berkeley, CA, USA
}

Received 13 September 2018; accepted 9 October 2018

\begin{abstract}
.
BACKGROUND: Anthocyanins, flavonoids and organic acids widely occurring in extracts of the fruits of Aristotelia chilensis ("Maqui"), concertedly acts on the expression of cyclooxygenase-2 (COX-2), NF-кB, HT-29 and Caco-2 colon cancer cell growth inhibition and on the production of inflammatory mediators.

OBJECTIVE: To assess the anti-inflammatory effects of extracts from fruits of "Maqui Berry", on the HT-29 and Caco-2 human colorectal cancer cell lines by measuring COX-2 and NF- $\mathrm{B}$ as well as their antioxidant activities.

MATERIAL AND METHODS: Methanol/water extracts and its partitions (acetone and ethyl acetate) from three varieties of "Maqui" were used to access their effects on growth of HT-29 and Caco-2 colon cancer cells, COX-2, NF- $\mathrm{B}$, NO formation, oxidations by DPPH, TBARS, FRAP and ORAC.

RESULTS: Fractions rich in anthocyanins, exhibited potent chemoprotective abilities on decreasing growth of HT-29 and Caco-2 colon cancer cells. The results indicated that the extracts suppressed the production of nitric oxide (NO), through the down-regulation of inducible nitric oxide synthases (iNOS). The structural features of the extracts correlate with the inhibition of NF-кB and COX-2 protein expressions and a potent antioxidant activity by assays of DPPH, FRAP, TBARS and ORAC. The inhibition of cell growth and NO production by selected extracts was dose-dependent with significant effects seen at concentration as low as 25.0 and $10.0 \mathrm{ppm}$, respectively.
\end{abstract}

\footnotetext{
*Corresponding author: Carlos L. Céspedes-Acuña, Department of Basic Sciences, Biochemistry and Phyto-Chemical Ecology Lab, Faculty of Sciences, Andres Bello Av. s/n, Chillan 3780000, Chillan, Chile. Tel.: +56 42 2463276/Ext. 77; Fax: +56 42 2463000; E-mail: cespedes.leonardo@gmail.com.
} 
CONCLUSIONS: The phenolics (anthocyanins, flavonoids, and organic acids) that occur in extracts from Maqui berry Aristotelia chilensis may provide therapeutic potential against colon cancer.

Keywords: Polyphenols, flavonoids, anthocyanins, organic acids, antioxidant activity, Aristotelia chilensis, Maqui berry

\section{Introduction}

Antioxidants are substances that delay the oxidation process, inhibiting the polymerization chain initiated by free radicals and other subsequent oxidizing reactions [1]. A growing body of literature points to the importance of natural antioxidants from many plants, which may be used to reduce cellular oxidative damage, provide protection against chronic diseases, including cancer, neurodegenerative, inflammation and cardiovascular diseases [2]. Occidental diets rich in saturated fatty acids, together with environmental pollution increase oxidative damage in the body. Given this constant exposure to oxidants, antioxidants may be necessary to counteract chronic oxidative effects, thereby improving the quality of life [3].

The increasing interest in the measurement of the antioxidant and chemoprotective activities of different plant samples is derived from the substantial evidence of the importance of Reactive Oxygen Species (ROS) [4-8]. On the other hand, the use of traditional medicine is widespread, and plants still present a large source of novel active biological compounds with interesting biological activities, in which the antioxidants may play a crucial role in health promoting activities $[9,10]$.

The numerous beneficial effects attributed to phenolic product [11-13] has given rise to a new interest in finding vegetal species with high phenolic content and relevant biological activity. Berries constitute a rich dietary source of phenolic antioxidant and bioactive properties [13-15]. Chilean Maqui Berry (MB) -a blackberryAristotelia chilensis (Mol) Stuntz (Elaeocarpaceae), an edible black-colored fruit, which reaches its ripeness between December to March, has a popular and very high consumption during these months in Central and South Chile and western of Argentina.

Previously, it has been reported the alkaloid composition of the leaves of A. chilensis [16-20]. On the other hand, in the continuation of the general screening program of Chilean flora with biological activities [20], up-to-date several studies report that fruit extracts of A. chilensis possess several biological activities including antioxidant, cardioprotection, enzymes inhibition and as mediators in inflammation, among other activities [20-27]. It has been enjoyed as an ethno-medicine for many years, it is also used as an anti-inflammatory agent on kidneys pains, diverse digestive ailments (intestinal tumors and stomach ulcers), fever and cicatrization injuries, antiinflammatory effects, antioxidant properties, antiatherogenic, hypoglycemia, antihaemolytic, and inhibit LDL oxidation [28-30].

Two important enzymes involved in activating the inflammatory response are inducible nitric oxide synthase (iNOS) and cyclooxygenase-2 (COX-2). iNOS and COX-2 can catalyze the synthesis of nitric oxide (NO) and prostaglandin E2 (PGE2), respectively, which in turn cause sepsis, sepsis shock, and systemic inflammatory response syndrome [31]. Therefore, inhibition of the expression of these enzymes or of their products can help to reduce inflammation and related conditions.

On the other hand, anthocyanins from many fruits showed a significant role in the cancer cell growth inhibitory activity [32-35]. Anthocyanin-rich extracts from berries and vegetables have been reported to slow down the growth of HT-29 colon cancer cells in vitro $[32,36]$. Besides, several studies have shown that anthocyanin-rich foods and anthocyanin pigments from food inhibited carcinogenesis in the colon [37-41].

In this study, we investigated the chemoprotective effects of extracts from fruits of A. chilensis by measuring in vitro antioxidant capacity, enzymes inhibition, and grow inhibition of HT-29 and CaCo- 2 cancer cells. The anthocyanin, flavonoids and organic acids constituents have been previously characterized and evaluated for 
the ability to reduce antioxidant and anti-inflammatory activity [21-25]. The anti-inflammatory properties were evaluated by investigating the NO and PGE2 production as well as iNOS and COX-2 expression [20].

\section{Material and methods}

\subsection{Biological material}

Fruits of Aristotelia chilensis (Mol) Stuntz (Elaeocarpaceae) were collected from fields near San Carlos City ("Buli" wild variety, sample S1), Coihueco City ("Coihueco" domesticated variety, provided for Soc Inmob. "Las Pataguas", sample S2), and Victoria City ("Las Raices" wild variety, sample S3), Chile. The samples of plants and fruits were identified botanically by Professor Dr. David S. Seigler (Plant Biology Department, University of Illinois at Urbana-Champaign, USA) and voucher specimens were deposited at the Herbarium of University of Illinois, (Ill, USA). The collected fruits were air-dried and kept frozen at $-80^{\circ} \mathrm{C}$ until use.

\subsection{Sample preparation}

For each sample fruits were separated in their main morphological parts (seed and pulp), the seeds were washed with a mixture of distilled water/MeOH (1:1) and then this liquid was collected with the methanol/water extract of pulp (containing $0.1 \% \mathrm{HCl}$ using distilled water). Thus, extract (A) was obtained for each sample of fruit. The methanol/water extract (A) was concentrated and re-dissolved in methanol: water (6:4), then partitioned into acetone (B) and ethyl acetate (C), leaving a residue (D) (Fig. 1). The acetone partition (B) showed the best antioxidant activity and it was used as leader for following experiments, furthermore extracts and fractions were processed as it was reported previously [21,23] and a complete metabolomic analyses of these samples will be published in another paper.

\subsection{Chemicals and solvents}

All reagents used were either analytical grade or chromatographic grade, 2,2'-azobis (2-aminopropane) dihydrochloride (AAPH), 2,2-diphenyl-1-picryl-hydrazyl (2,2-Diphenyl-1-(2,4,6-Trinitrophenyl, DPPH), Butylated Hydroxy Toluene (BHT; 2[3]-t-Butyl-4-hydroxytoluene), Trolox (6-hydroxy-2,5,7,8-tetramethylchroman-2carboxylic acid), quercetin, Folin-Ciocalteu reagent, (+)-Catechin, 2-thiobarbituric acid (TBA), 2,4,6-tripyridils-triazine (TPTZ), ABTS (2,2-azino-bis(3-ethylbenzothyazolin-6-sulfonic ammonium) salt), dichlorofluorescein diacetate, $\mathrm{FeCl}_{3} \bullet 6 \mathrm{H}_{2} \mathrm{O}$, hypoxanthine, xanthine oxidase, dihydroethydium (DHE), fluorescein disodium (FL) (3',6'-dihydroxy-spiro[isobenzofuran-1 [3H], 9[9H]-xanthen]-3-one, tetramethoxypropane (TMP), 1,1,3,3-tetraethoxypropane (TEP), MTT, Tris-hydrochloride buffer, phosphate buffered saline (PBS), phosphatidylcholine, $\mathrm{FeSO}_{4}$, trichloroacetic acid, Sulforhodamine B Solution $0.4 \%$ in $1 \%$ Acetic Acid, Trichloroacetic Acid, 50\%, Acetic Acid Solution, 10\%, Tris Base Solution, were purchased from Sigma-Aldrich, St. Louis, MO (now Merck). Methanol, $\mathrm{CH}_{2} \mathrm{Cl}_{2}, \mathrm{CHCl}_{3}, \mathrm{NaCl}, \mathrm{KCl}, \mathrm{KH}_{2} \mathrm{PO}_{4}, \mathrm{NaHPO}_{4}, \mathrm{NaOH}, \mathrm{KOH}, \mathrm{HCl}$, sodium acetate trihydrate, glacial acetic acid silica gel $\mathrm{GF}_{254}$ analytical chromatoplates, silica gel grade $60,\left(70-230,60 \mathrm{~A}^{\circ}\right)$ for column chromatography, n-hexane, and ethyl acetate were purchased from Merck.

\subsection{Reduction of the 2,2-Diphenyl-1-Picrylhydrazyl Radical}

Extracts and partitions were chromatographed on TLC and examined for antioxidant effects by spraying the TLC plates with DPPH reagent. Specifically, the plates were sprayed with $0.2 \%$ DPPH in methanol [42, 43]. Furthermore each fraction was analyzed with DPPH in microplates of 96 wells as follow: extracts, partitions and fractions $(50 \mu \mathrm{L})$ were added to $150 \mu \mathrm{L}$ of DPPH $(100 \mu \mathrm{M}$, final concentration) in methanol (The microtiter 


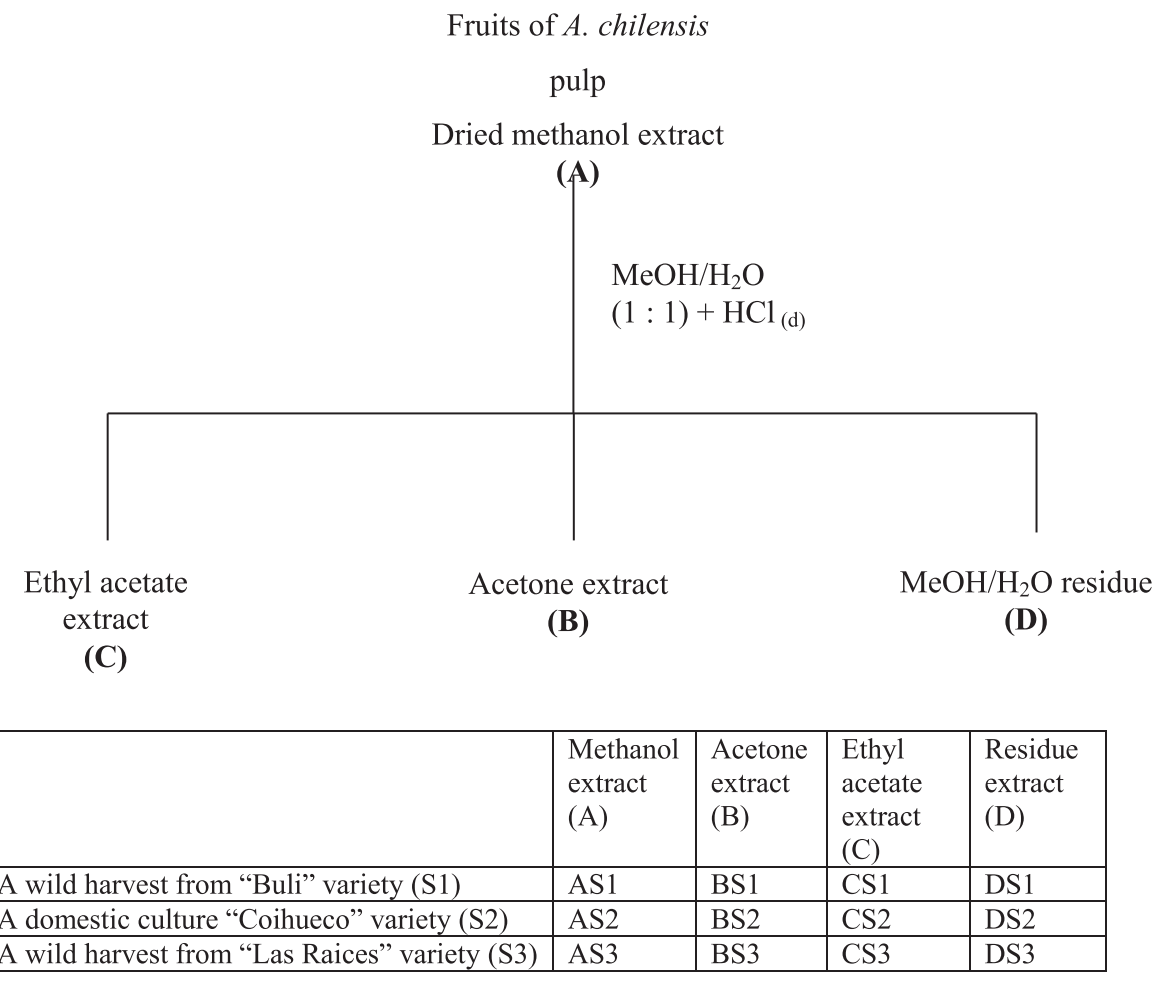

Fig. 1. Methods of obtaining extracts from three Maqui berry Aristotelia chilensis varieties. For the three varieties, same methodology was used.

plate was immediately placed in an Biotek ${ }^{\mathrm{TM}}$ Model ELx808, Biotek Instruments, Inc., Winooski, VT) and their absorbance read at $515 \mathrm{~nm}$ after $30 \mathrm{~min}[44,45]$. Quercetin and $\alpha$-tocopherol were used as standards.

\subsection{Oxygen radical absorbance capacity estimation}

Oxygen Radical Absorbance Capacity measures antioxidant scavenging activity of a sample or standard against peroxyl radicals generated from AAPH at $37^{\circ} \mathrm{C}$ using FL, Trolox as the standard [46, 47]. The assay was carried out in black-walled 96-well plates (Fischer Scientific, Hanover Park, IL), at $37^{\circ} \mathrm{C}$ in $75 \mathrm{mM}$ phosphate buffer ( $\mathrm{pH}$ 7.4). The following reactants were added in the following order: Sample or Trolox (20 $\mu \mathrm{L} ; 7 \mu \mathrm{M}$ final concentration) and fluorescein $(120 \mu \mathrm{L} ; 70 \mathrm{nM}$ final concentration). The mixture was preincubated for $15 \mathrm{~min}$ at $37^{\circ} \mathrm{C}$, after which AAPH $(60 \mu \mathrm{L} ; 12 \mathrm{mM}$ final concentration) was added (final volume $200 \mu \mathrm{L})$. The microtiter plate was immediately placed in a Biotek ${ }^{\mathrm{TM}}$ Model FLx800 (Biotek Instruments, Inc., Winooski, VT) fluorescence plate reader set, and the fluorescence was recorded every minute for $120 \mathrm{~min}$, using an excitation $\lambda=485 / 20 \mathrm{~nm}$ and emission $\lambda=582 / 20 \mathrm{~nm}$, to reach a $95 \%$ loss of fluorescence. Results are expressed as $\mu \mathrm{mol}$ Trolox equivalents (TE) per gram. All tests were conducted in triplicate.

\subsection{Ferric reducing antioxidant power estimation}

The FRAP assay was performed as previously described by Benzie and Strain [48]. Reagents were freshly prepared and mixed in the proportion 10:1:1, for $\mathrm{A}: \mathrm{B}: \mathrm{C}$, where $\mathrm{A}=300 \mathrm{mM}$ sodium acetate trihydrate/glacial acetic acid buffer $\mathrm{pH} 3.6 ; \mathrm{B}=10 \mathrm{mM}$ TPTZ in $40 \mathrm{mM} \mathrm{HCl}$ and $\mathrm{C}=20 \mathrm{mM} \mathrm{FeCl}_{3}$. Catechin was used for a 
standard curve (5-40 $\mu \mathrm{M}$ final concentration) with all solutions, including samples, dissolved in sodium acetate trihydrate/glacial acetic acid buffer. The assay was carried out in 96 -well plates, at $37^{\circ} \mathrm{C}$ at $\mathrm{pH} 3.6$, using $10 \mu \mathrm{L}$ sample or standard plus $95 \mu \mathrm{L}$ of the mixture of regents shown above. After 10 min incubation at RT, absorbance was read at $593 \mathrm{~nm}$. Results are expressed as $\mu \mathrm{mol}$ Catechin equivalents (CatE) per gram of sample. All tests were conducted in triplicate.

\subsection{Estimation of total polyphenol content}

The total phenolic content of extracts was determined using the Folin-Ciocalteu reagent $[49,50]: 10 \mu \mathrm{L}$ sample or standard (10-100 $\mu \mathrm{M}$ Catechin) plus $150 \mu \mathrm{L}$ diluted Folin-Ciocalteu reagent (1:4 reagent: water) was placed in each well of a 96 well plate, and incubated at RT for $3 \mathrm{~min}$. Following addition of $50 \mu \mathrm{L}$ sodium carbonate ( $2: 3$ saturated sodium carbonate: water) and a further incubation of $2 \mathrm{~h}$ at RT, absorbance was read at $725 \mathrm{~nm}$. Results are expressed as $\mu \mathrm{mol}$ Cat E per gram. All tests were conducted in triplicate (Fig. 4).

\subsection{Estimation of lipid peroxidation using rat brain}

As an index of lipid peroxidation, TBARS levels were measured using rat brain homogenates according to the method described by $\mathrm{Ng}$ et al. [51], with some modifications. Adult male Wistar rats (200-250 g) were provided by UBIPRO FES-Iztacala, UNAM, and their use was approved by the Animal Care and Use Committee (PROJ.-NOM 087-ECOL-SSA 1-2000). Rats were maintained at $25^{\circ} \mathrm{C}$ on a $12 / 12 \mathrm{~h}$ light-dark cycle with free access to food and water and sacrificed under mild ether anesthesia. Cerebral tissue was rapidly dissected from the whole brain and homogenized in phosphate-buffered saline $\left(0.2 \mathrm{~g} \mathrm{KCl}, 0.2 \mathrm{~g} \mathrm{KH}_{2} \mathrm{PO}_{4}, 8 \mathrm{~g} \mathrm{NaCl}\right.$ and $2.16 \mathrm{~g}$ $\mathrm{NaHPO}_{4} .7 \mathrm{H}_{2} \mathrm{O} / \mathrm{L}$, pH 7.4) to produce a 1 in 10 homogenate, w/v [52]. The homogenate was centrifuged for $10 \mathrm{~min}$ at $3400 \mathrm{rpm}$, and the resulting pellet was discarded. Protein content of the supernatant was measured by the method of Lowry [53], and samples were adjusted to $2.5 \mathrm{mg}$ protein/mL with phosphate buffered saline (PBS). The supernatant ( $400 \mu \mathrm{L}, 1 \mathrm{mg}$ protein) was pre-incubated with sample $(50 \mu \mathrm{L})$ at $37^{\circ} \mathrm{C}$ for $30 \mathrm{~min}$, then peroxidation was initiated by the addition of $50 \mu \mathrm{L}$ freshly prepared $\mathrm{FeSO}_{4}$ solution (final concentration $10 \mu \mathrm{M}$ ) and incubated at $37^{\circ} \mathrm{C}$ for an additional $1 \mathrm{~h} \mathrm{[51].}$

The TBARS assay was determined as described by Ohkawa et al. [54] with the modification that $0.5 \mathrm{~mL}$ TBA reagent (1\% thiobarbituric acid in $0.05 \mathrm{~N} \mathrm{NaOH}$ and $30 \%$ trichloroacetic acid, 1:1) was used, and that the final solution was cooled on ice for $10 \mathrm{~min}$, centrifuged at $10,000 \mathrm{rpm}$ for $5 \mathrm{~min}$, and then heated at $95^{\circ} \mathrm{C}$ in a boiling water bath for $30 \mathrm{~min}$. After cooling on ice, the absorbance was read at $532 \mathrm{~nm}$ in a Spectronic Genesys 5 spectrophotometer. Quercetin and BHT were used as positive controls. Concentrations of TBARS were calculated using a TMP standard curve [55]. Results are expressed as nmoles TBARS per mg of protein, with percent inhibition after 30 min calculated as the inhibition ratio (IR).

$$
\operatorname{IR}(\%)=(\mathrm{C}-\mathrm{E}) / \mathrm{C} \times 100 \% .
$$

Where $\mathrm{C}=$ absorbance of the control and $\mathrm{E}=$ absorbance of the test sample. These values were plotted against the $\log _{10}$ of the concentrations of individual extracts and fractions, and a decrease of $50 \%$ in peroxidation was defined as the $\mathrm{EC}_{50}$.

\subsection{Cell culture}

Raw 264.7 murine macrophage cells were obtained from American Type Culture Collection (ATCC, Rockville, MD, USA) and maintained in Dulbecco's modified Eagles Medium (DMEM) containing 100 units $/ \mathrm{mL}$ penicillin G sodium, 100 units $/ \mathrm{mL}$ streptomycin, supplemented with $10 \%$ heat inactivated FBS under endotoxin-free conditions at $37^{\circ} \mathrm{C}$ in a $5 \% \mathrm{CO} 2$ atmosphere [56]. 


\subsection{Cell stimulation}

Raw 264.7 cells were plated in T-25 tissue culture flasks $(3.0 \times 106$ cells/flask). Cells were incubated in DMEM for $24 \mathrm{~h}$. The cells were replaced with new media DMEM 10\% FBS with or without LPS $(1 \mu \mathrm{g} / \mathrm{mL}$, from Escherichia coli, serotype 0111:B4), plus the plant extracts, fractions, or pure compounds and incubated for $12 \mathrm{~h}$. Cells were then washed with PBS and lysed with $\mathrm{NaCl} 250 \mathrm{mM}$, HEPES $50 \mathrm{mM} \mathrm{pH}$ 7.9, EDTA $5 \mathrm{mM}$, Nonidet p-40 0.1\%, DTT $0.5 \mathrm{mM}$, PMSF $1 \mathrm{mM}$, Na-orthovanadate $0.5 \mathrm{mM}$, NaF $3 \mathrm{mM}$ and Protease inhibitor cocktail $1 \mu$ L by 1-3 X 107 cells. Protein was determined by the Bio-Rad method [56].

\subsection{Western blotting analysis}

Total protein $(40 \mu \mathrm{g} / \mathrm{lane})$ was loaded on a $7.5 \%$ SDS polyacrylamide gel under standard conditions and electro-blotted to an NTT membrane in $15 \%$ methanol, $25 \mathrm{mM}$ Tris and $192 \mathrm{mM}$ glycine. The membrane was blocked with nonfat milk in TTBS saline $1 \mathrm{~h}$ at $37^{\circ} \mathrm{C}$ or overnight at $4^{\circ} \mathrm{C}$ before incubation with primary antibody (1:500 for iNOS, 1:1000 dilutions for COX-2) in 5\% milk in TTBS for $1 \mathrm{~h}$ at $37^{\circ} \mathrm{C}$. After thoroughly washing, the membrane was incubated with a secondary antibody radish peroxidase $(1: 25,000)$ for $1 \mathrm{~h}$ at $37^{\circ} \mathrm{C}$. The immunoreactive bands were visualized using an enhanced chemoluminescence system Amersham [56].

\subsection{Toxicity assay}

3-(4,5-dimethylthiazole-2-yl)-2,5-diphenyl tetrazolium bromide (MTT). 80,000 cells/well were plated under the same conditions as cell stimulation. After $12 \mathrm{~h}$ incubation, MTT $(20 \mu \mathrm{L}, 5 \mathrm{mg} / \mathrm{ml}$ in PBS) was added to each well and incubated for $1.5 \mathrm{~h}$ in a $\mathrm{CO} 2$ incubator at $37^{\circ} \mathrm{C}$. The medium was removed and DMSO (200 $\left.\mu \mathrm{L}\right)$ was added to dissolve the absorbed MTT crystals. The plate (96 wells) was incubated for another 15 min before measuring the absorbance at $550 \mathrm{~nm}$ (Biotek ELx800) [56].

\subsection{Measurement of nitric oxide formation by iNOS activity in LPS- stimulated RAW 264.7 cells}

Macrophage cells were maintained in DMEM supplemented with penicillin/streptomycin and 10\% FBS at $37^{\circ} \mathrm{C}, 5 \% \mathrm{CO} 2$ in humidified air. For evaluating the inhibitory activity of extracts on iNOS, the cells in $10 \%$ FBS $\lrcorner$ DMEM without extracts were plated in 96-well plates (500,000 cells/well), and then incubated for $24 \mathrm{~h}$.

The cells were replaced with new media, and then incubated in the medium with $1 \mu \mathrm{g} / \mathrm{mL}$ of LPS and extracts. After additional $12 \mathrm{~h}$ incubation, the media were removed and analyzed for nitrite accumulation as an indicator of NO production by the Griess reaction. Briefly, $50 \mu \mathrm{L}$ of Griess reagent $(0.1 \%$ naphthylethylenediamine and $1 \%$ sulfanilamide in $5 \% \mathrm{H} 3 \mathrm{PO} 4$ solution) were added to $50 \mu \mathrm{L}$ of each supernatant from LPS, or extract-treated cells in triplicate. The plates ( 96 wells) were incubated for $5 \mathrm{~min}$, and then were read at $570 \mathrm{~nm}$ against a standard curve of sodium nitrite (Biotek ELx800) [56].

\subsection{DCFH assay}

80,000 cells/well were plated under the same conditions same as cell stimulation at room temperature. After the $12 \mathrm{~h}$ incubation, $200 \mu \mathrm{L}$ medium was added plus $100 \mu \mathrm{M}$ DCFH per $30 \mathrm{~min}$, the medium was removed and the cells were washed and added with $200 \mu \mathrm{L}$ PBS (pH 7.5) and the plate was placed in the reader and the fluorescence recorded every minute for $120 \mathrm{~min}$, using an excitation $1=485 / 20$ and emission $1=582 / 20$ (Biotek FLx800) [56]. 


\subsection{HT-29 colon cancer cell line}

HT-29 colon cancer cell line derived from human colorectal adenocarcinoma cells (HTB 38; American Type Culture Collection, VA, USA) were grown at $37^{\circ} \mathrm{C}$ in a Nuaire ${ }^{\mathrm{TM}}$ IR Autoflow $\mathrm{CO} 2$ Water-Jacketed Incubator at a modified atmosphere (5\% CO2, 95\% O2) in McCoy's 5A Medium with L-glutamine (Fisher Scientific, Florence, KY) and supplemented with 10\% fetal bovine serum (FBS) (Invitrogen Corp., Carlsbad, CA). They were seeded at a volume of $1 \times 10^{4}$ per well in a 96 well plate. Suspended cells were counted using a Nikon Eclipse 50i Brightfield Microscope and a Reichert Bright-Line hemocytometer (Hausser Scientific; Horsham, PA) to estimate total viable cell concentration. Cultures were split 1:5 when monolayers were $70-80 \%$ confluent using Dulbecco's Phosphate Buffered Saline solution (DPBS) and 2.5\% trypsin (Lonza, Walkersville, MD).

Cultured cells were fed fresh media every 3 days. Growth of HT-29 cell line was determined by microscopic examination. Using the 10x lens of the microscope, cells were counted on 5 primary squares of the hemocytometer using a hand counter. To calculate HT-29 cell concentration, the following formula was used:

Cells $/ \mathrm{mL}=($ Total $\#$ cells counted $) /($ Number of primary squares counted $) \times 1 \times 10^{4}$. Cell cultures were maintained in $75 \mathrm{~cm}^{2}$ Flasks with canted necks (Fisher Scientific, Florence, KY). All cell culture experiments were performed with the initial 20 passages.

HT-29 colon cancer cells were seeded at $10^{4}$ cells $/ \mathrm{ml}$ and allowed to grow for 24 hours. After 24 hours the HT-29 colon cancer cells were treated with anthocyanin rich extract from Maqui berry samples (30, 15, 10, 5 and $1.0 \mu \mathrm{g} / \mathrm{mL}$ of media) for 48 hours [32].

HT-29 colon cancer cell growth inhibition was determined after 48 hours of incubation at the different anthocyanin concentrations by using the Sulforhodamine B assay (SRB) at $490 \mathrm{~nm}$. Each treatment had 4 replicates and every treatment was repeated at least 4 times. The percentage of growth inhibition is calculated as follows:

$$
\% \text { Growth Inhibition }=100-(\text { Ttrt }-\mathrm{T} 0) \times 100 /(\mathrm{Tctr}-\mathrm{T} 0)
$$

Where T0: Time zero. The absorbance of sample at $490 \mathrm{~nm}$ after first 24 hours incubation period prior to anthocyanin treatment. Ttrt: Absorbance of sample at $490 \mathrm{~nm}$ after anthocyanin treatment. Tctr: Absorbance of sample at $490 \mathrm{~nm}$ after total incubation (72 hours) without anthocyanin treatment [56].

\subsection{Antiproliferative studies}

Caco-2 cells (ATCC\#HTB-37) were cultured in DMEM medium supplemented with $10 \%$ FBS, $100 \mathrm{U} / \mathrm{ml}$ penicillin, $100 \mathrm{U} / \mathrm{mL}$ streptomycin, and $2 \mathrm{mM} \mathrm{L}$-glutamine, at $37^{\circ} \mathrm{C}$ in an atmosphere with $5 \% \mathrm{CO}_{2}$. The culture medium was changed every $48-72 \mathrm{~h}$ and the cells were tripsinized when confluence reached approximately $80 \%$.

To study the antiproliferative effect of the extracts, the cells were seeded in 96 microplates, using $5 \times 10^{4}$ cells $/ 100 \mu \mathrm{L}$ in each well. Cells were grown for $120 \mathrm{~h}(\mathrm{Caco}-2)$. The culture medium was replaced by DMEM containing different concentrations of A. chilensis Maqui berry extracts $(100 \mu \mathrm{g}, 50 \mu \mathrm{g}, 25 \mu \mathrm{g}$ and $12.5 \mu \mathrm{g}$ cyanidin-3-glucoside equivalents $/ \mathrm{mL}$ of media). Cells were incubated for $4 \mathrm{~h}$ at $37^{\circ} \mathrm{C}$ in with $5 \% \mathrm{CO}_{2}$. The quantification of the antiproliferative effect was carried out using the MTT method described in Chen et al. [57]. The absorbance of each well was compared to the control cells, without extract. IC $_{50}$ represents the extract concentration that causes $50 \%$ decrease in cell viability. This value was calculated from a regression curve in which the cell viability was represented versus the extract concentration in each well. The values are the mean of 4 times 8 replicates.

\subsection{Cell viability assays}

The cytotoxicity activities of $A$. chilensis extracts against Caco- 2 cells were determined using Sulforhodamine B (SRB) assay [58, 59]. The Caco- 2 cells were seeded in 96 well tissue plates at a density of $8 \times 10^{5}$ cell $/ \mathrm{ml}$ in $100 \mu \mathrm{l}$ medium DMEM per well for $24 \mathrm{~h}$ in the $\mathrm{CO}_{2}$ incubator. After $8 \mathrm{~h}$, various concentrations of Maqui berry 
extracts were added to the medium $(100 \mu \mathrm{g}, 50 \mu \mathrm{g}, 25 \mu \mathrm{g}$ and $12.5 \mu \mathrm{g}$ cyanidin-3-glucoside equivalents $/ \mathrm{mL}$ of media). After incubation for $48 \mathrm{~h}$, the cell monolayers were washed with $100 \mu \mathrm{l}$ phosphate buffered saline (PBS) fixed with trichloroacetic acid and stained for $30 \mathrm{~min}$ with $0.4 \%$ (w/v) Sulforhodamine B (SRB-Sigma Chemical Co., St. Louis, MO, USA) dissolved in $1 \%$ acetic acid. The dye was removed by four washes with $1 \%$ acetic acid. Protein-bound dye was extracted with $10 \mathrm{mM}$ unbuffered Tris-base solution [tris (hydroxymethyl)aminomethane] for determining the sample's optical density in a computer-interfaced, 96-well microtiter plate reader (BIOTEK®, ELX405, Winooski, VT, USA). Vehicle controls covering all the concentrations of the solvents were performed. All standard compounds and solutions prepared were protected from light using amber vials and the protection of plastic microtubes, as well as cell culture plates using aluminum foil.

\subsection{Statistical analysis}

Data were analyzed by one-way ANOVA followed by Dunnett's test for comparisons against control. Values of $p \leq 0.05(*)$ and $p \leq 0.01(* *)$ were considered statistically significant and the significative differences between means were identified by GLM Procedures. In addition, differences between treatment means were established with a Student-Newman-Keuls (SNK) test. The $\mathrm{IC}_{50}$ values for each analysis were calculated by Probit analysis. Complete statistical analyses were performed using the MicroCal Origin 8.5 statistical and graphs PC program.

\section{Results and discussion}

\subsection{Antioxidant}

Extracts were evaluated for oxygen radical absorption capacity (ORAC), ferric reducing antioxidant power (FRAP), 2,2-diphenyl-1-picryl-hydrazil (DPPH) radical scavenging, and an estimation of lipid peroxidation in rat brain and in liposomes through the inhibition of formation of thiobarbituric acid reactive species (TBARS).

Antioxidant activities were strongly correlated with phenolic content of the samples. The most active sample were fractions BS1, BS2, BS3, AS1, AS2 and AS3 in all bioassays used and the four extract types (MeOH (A), acetone (B), ethyl acetate (C) and residue (D) were compared for activity against butylated hydroxy toluene (BHT), and tocopherol as positive control (Fig. 2 (A-D)). The samples AS1, AS3, BS1 and BS3 were found to have $\mathrm{IC}_{50}$ values of $1.5,3.6,1.3$, and $3.1 \mathrm{ppm}$, respectively, in DPPH assay and 2.3, 4.9, 3.6, and 5.6 ppm, respectively, against TBARS formation on rat brain procedures (Table 1). Consistent with this finding, $\mathrm{MeOH}$ (A) and acetone (B) extracts of wild extracts had the greatest ORAC and FRAP values shown in percentage of activity (Table 2). The $\mathrm{MeOH}$ extract protects against stress oxidative reducing the concentration of the MDA a lipid peroxidation index. As reported, A. chilensis protected animals from heart damage as it seems to be by the incidence of reperfusion dysrhythmias, and the no-recovery of sinus rhythm [21]. On the other hand, $\mathrm{MeOH}$ extract was able to prevent these harmful events in the animal's heart by diminishing lipid oxidation. These results show that Maqui berry could be useful as antioxidant and cardioprotective sources [21].

The DPPH radical scavenging assay was used first as a screen for antioxidant components within the primary extracts [42, 43]. As shown in Fig. 2 and Table 1, the methanol and acetone partitions (A and B, respectively) had higher inhibitory activity against DPPH radical formation compared to the other partitions (C and D). Almost all these extracts exhibited a concentration-dependence in their DPPH radical scavenging activities, particularly BS1, which showed the highest activity (95\% inhibition) at a concentration of $15.1 \mathrm{ppm}$ (Fig. 2B). This action was greater than that of $\alpha$-tocopherol, caused only $53.8 \%$ quenching at $31.6 \mathrm{ppm}$ and it is very similar to ferulic and $p$-coumaric acids with $\mathrm{IC}_{50}$ values of 5.1 and $7.8 \mathrm{ppm}$, respectively (data not shown).

The lower $\mathrm{IC}_{50}$ value for partition BS1 $(1.3 \mathrm{ppm})$ than any of the extracts A and B, might be due to a synergistic effect of the components (mainly organic acid derivatives, anthocyanins and flavonoids) within this extract, similar 
A

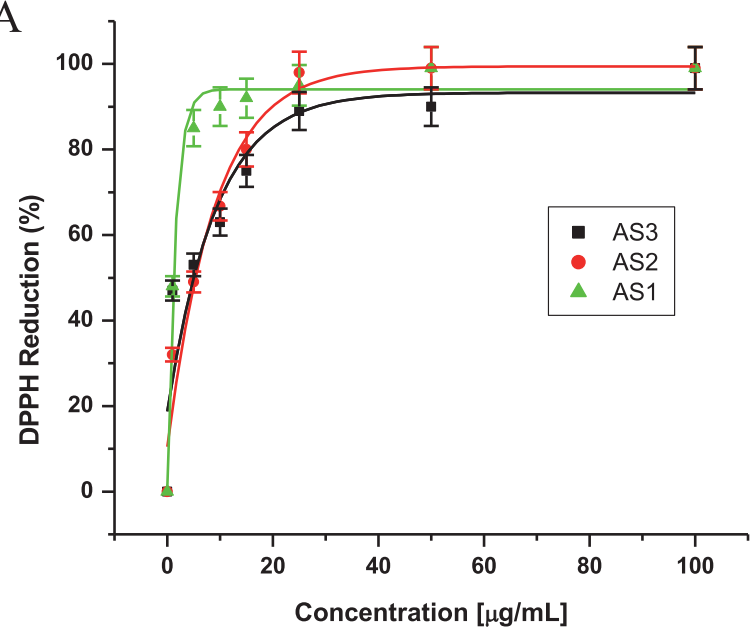

$\mathrm{C}$

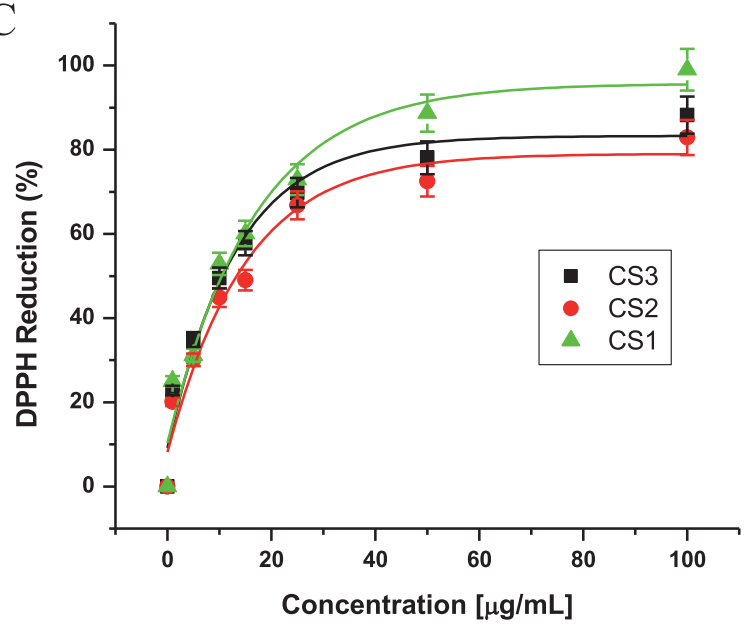

$\mathrm{B}$

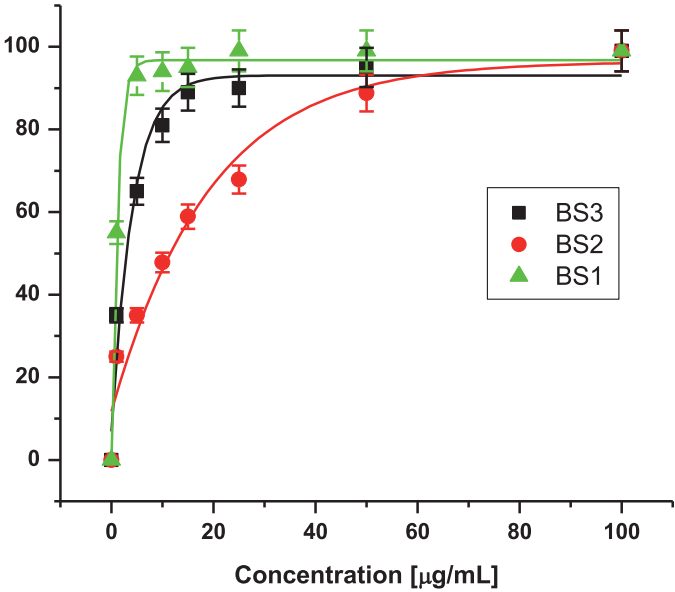

$\mathrm{D}$

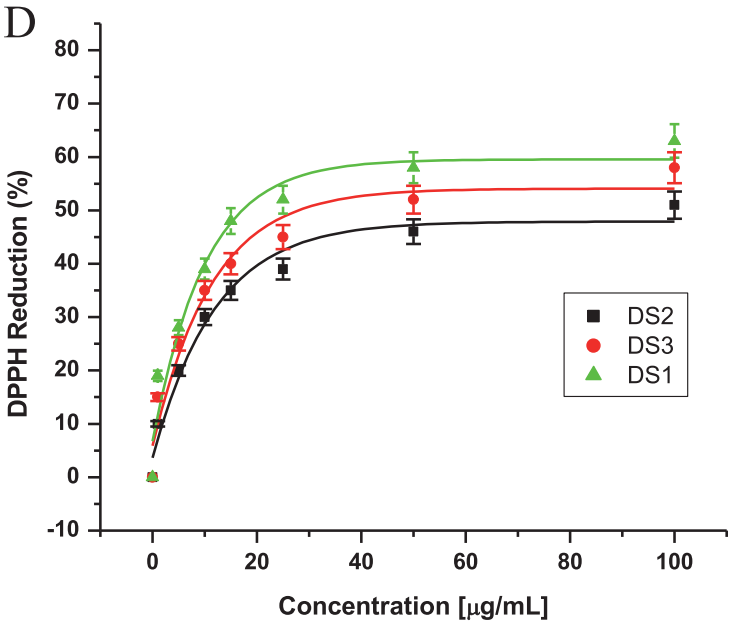

Fig. 2. Scavenging of DPPH radicals by extracts from three varieties of Maqui berry Aristotelia chilensis. (A) AS1, AS2, AS3, (B) BS1, BS2, BS3, (C) CS1, CS2, CS3, (D) DS1, DS2, DS3. For explanation of the extracts and partitions, see Fig. 1.

to the reports for components of Vaccinium corymbosum and V. angustifolium fruits [60, 15], where the acetone and $\mathrm{MeOH}$ partitions were the most active extracts.

Of the many biological macromolecules, including carbohydrates, lipids, proteins, and DNA, that can undergo oxidative damage in the presence of ROS, membrane lipids are especially sensitive to oxidation from this physiological process [61]. For this reason, brain homogenates were used for the investigation of lipid peroxidation as an assessment of oxidative stress. The capacity of extracts to prevent lipid peroxidation was assayed using malondialdehyde formation as an index of oxidative breakdown of membrane lipids, following incubation of rat brain cortical homogenates with the oxidant chemical species $\mathrm{Fe}^{2+}$. Ferrous ion both stimulates lipid peroxidation and promotes decomposition of lipids peroxides once formed, generating highly reactive intermediates such as hydroxyl radicals, perferryl and ferryl species [62]. Extract B was the most effective, C and D were least effective, but none was as effective as A or B extracts, or quercetin and BHT in inhibiting lipid peroxidation. Table 1 shows the tabulated data that provide $\mathrm{IC}_{50}$ values for DPPH and TBARS; extract A clearly showed the greatest activity. Thus, extract A reduced lipid peroxidation in a dose-dependent manner, and proved to be 
Table 1

$\mathrm{IC}_{50}$ values of three varieties of Maqui berry Aristotelia chilensis for inhibition of oxidative damage ${ }^{5}$

\begin{tabular}{lccc}
\hline Extracts $^{1}$ & DPPH $^{2}$ & TBARS $^{3}$ & TBARS $^{4}$ \\
\hline AS1 & $1.5 \pm 0.4 \mathrm{~b}$ & $2.3 \pm 0.4 \mathrm{~b}$ & $5.4 \pm 0.5 \mathrm{~b}$ \\
AS2 & $6.1 \pm 0.9 \mathrm{c}$ & $11.3 \pm 1.1 \mathrm{c}$ & $19.1 \pm 1.4 \mathrm{c}$ \\
AS3 & $3.6 \pm 0.5 \mathrm{~b}$ & $4.9 \pm 0.4 \mathrm{~b}$ & $9.9 \pm 0.9 \mathrm{~d}$ \\
BS1 & $1.3 \pm 0.2 \mathrm{a}$ & $3.6 \pm 0.5 \mathrm{a}$ & $4.4 \pm 0.8 \mathrm{a}$ \\
BS2 & $11.2 \pm 1.8 \mathrm{c}$ & $34.2 \pm 2.9 \mathrm{~d}$ & $8.7 \pm 1.3 \mathrm{~d}$ \\
BS3 & $3.1 \pm 0.2 \mathrm{~d}$ & $5.6 \pm 1.2 \mathrm{e}$ & $4.8 \pm 0.8 \mathrm{a}$ \\
CS1 & $9.0 \pm 2.3 \mathrm{e}$ & $10.9 \pm 0.8 \mathrm{c}$ & $31.2 \pm 3.9 \mathrm{e}$ \\
CS2 & $15.9 \pm 2.1 \mathrm{f}$ & $20.4 \pm 3.2 \mathrm{f}$ & $47.8 \pm 2.2 \mathrm{f}$ \\
CS3 & $10.6 \pm 2.5 \mathrm{e}$ & $15.7 \pm 5.9 \mathrm{~g}$ & $21.8 \pm 2.8 \mathrm{~g}$ \\
\hline
\end{tabular}

${ }^{1}$ See Fig. 1 for an explanation of extracts and partitions. ${ }^{2} \mathrm{IC}_{50}$ for inhibition of diphenyl picryl hydrazyl radical formation. ${ }^{3} \mathrm{IC}_{50}$ for inhibition of peroxidation of lipids, estimated as thiobarbituric acid reactive substances for rat brain procedures. ${ }^{4}$ IC50 for inhibition of peroxidation of lipids, estimated as thiobarbituric acid reactive substances for liposomes procedures. ${ }^{5}$ Values are expressed as $\mu \mathrm{g} / \mathrm{mL}$ (ppm), See Methods for details. Mean $\pm \mathrm{SD}, n=3$. Different letters show significant differences at $(P<0.05)$, using Duncan's multiple-range test.

Table 2

Antioxidant capacity of three varieties of Maqui berry Aristotelia chilensis, measured by the ORAC and the FRAP assays

\begin{tabular}{|c|c|c|c|c|}
\hline \multirow[t]{2}{*}{ Sample $^{a}$} & \multicolumn{3}{|c|}{ ORAC $^{b}$} & \multirow{2}{*}{$\begin{array}{c}\text { FRAP }^{\mathrm{c}} \\
\mu \mathrm{mol} \mathrm{Cat} \mathrm{E/g} \mathrm{extract}\end{array}$} \\
\hline & {$[\mu \mathrm{g} / \mathrm{mL}]$} & $\mu \mathrm{mol} \mathrm{TE} / \mathrm{g}$ extract & {$[\mu \mathrm{g} / \mathrm{mL}]$} & \\
\hline AS1 & 10.0 & $30790.9 \pm 120.2 \mathrm{a}$ & 25.0 & $19973.9 \pm 44.1 \mathrm{a}$ \\
\hline $\mathrm{AS} 2$ & 10.0 & $26288.7 \pm 535.9 \mathrm{~b}$ & 25.0 & $15664.9 \pm 23.3 b$ \\
\hline AS3 & 10.0 & $28480.9 \pm 185.8 \mathrm{c}$ & 25.0 & $19199.4 \pm 11.5 \mathrm{a}$ \\
\hline BS1 & 10.0 & $27663.4 \pm 559.3 b$ & 25.0 & $21200.1 \pm 36.4 \mathrm{c}$ \\
\hline $\mathrm{BS} 2$ & 10.0 & $19760.9 \pm 197.1 \mathrm{~d}$ & 25.0 & $18100.9 \pm 19.3 \mathrm{a}$ \\
\hline BS3 & 10.0 & $22560.8 \pm 190.1 \mathrm{e}$ & 25.0 & $19939.9 \pm 12.7 \mathrm{a}$ \\
\hline $\mathrm{CS} 1$ & 10.0 & $13980.8 \pm 129.7 f$ & 25.0 & $6798.1 \pm 10.9 \mathrm{~d}$ \\
\hline $\mathrm{CS} 2$ & 10.0 & $11569.9 \pm 123.6 \mathrm{~g}$ & 25.0 & $6682.4 \pm 12.9 \mathrm{~d}$ \\
\hline $\mathrm{CS} 3$ & 10.0 & $15656.5 \pm 131.8 \mathrm{f}$ & 25.0 & $6998.2 \pm 19.3 \mathrm{~d}$ \\
\hline
\end{tabular}

${ }^{\mathrm{a}}$ Extracts A (Methanol/water (1:1)), B (Acetone partition), C (Ethyl Acetate partition) from three varieties of Maqui berry Aristotelia chilensis. For details, see Fig. 1, and Material and Methods. ${ }^{b}$ Expressed as $\mu \mathrm{mol} \mathrm{TE} / \mathrm{g}$ extract, ( $\mu$ mol of Trolox Equivalents / gram extract). Mean $\pm \mathrm{SD}$, $n=3$. Different letters show significant differences at $(P<0.05)$, using Duncan's multiple-range test. ${ }^{c}$ Expressed as $\mu \mathrm{mol}$ CatE/g extract, ( $\mu$ mol of Catequin Equivalents / gram extract). Mean $\pm \mathrm{SD}, n=3$. Values with the same letter are not significantly different $(P<0.05)$.

an excellent antioxidant, evidenced by its low $\mathrm{IC}_{50}$ value when analyzed by both TBARS and DPPH (Figs. 2 and 3).

When the relative contribution of each extract to the total antioxidant activity was evaluated using DPPH and TBARS (Figs. 2 and 3, respectively), all extracts except D fraction showed good protective effect, with $\mathrm{IC}_{50}$ values between 1.3 and $47.8 \mathrm{ppm}$ for both assays (Table 1, Fig. 4). It is noteworthy that the value for BS1 and AS1 is very low when it is compared with both values for flavonoids and anthocyanins in general, as well as for morin or quercetin $[63,64]$. Currently, we are carrying out qualitative and quantitative analysis on these extracts.

It has been reported that the antioxidant activity of many compounds of botanical origin is proportional to the phenolic content [65], suggesting a causative relationship between total phenolic content and antioxidant activity 

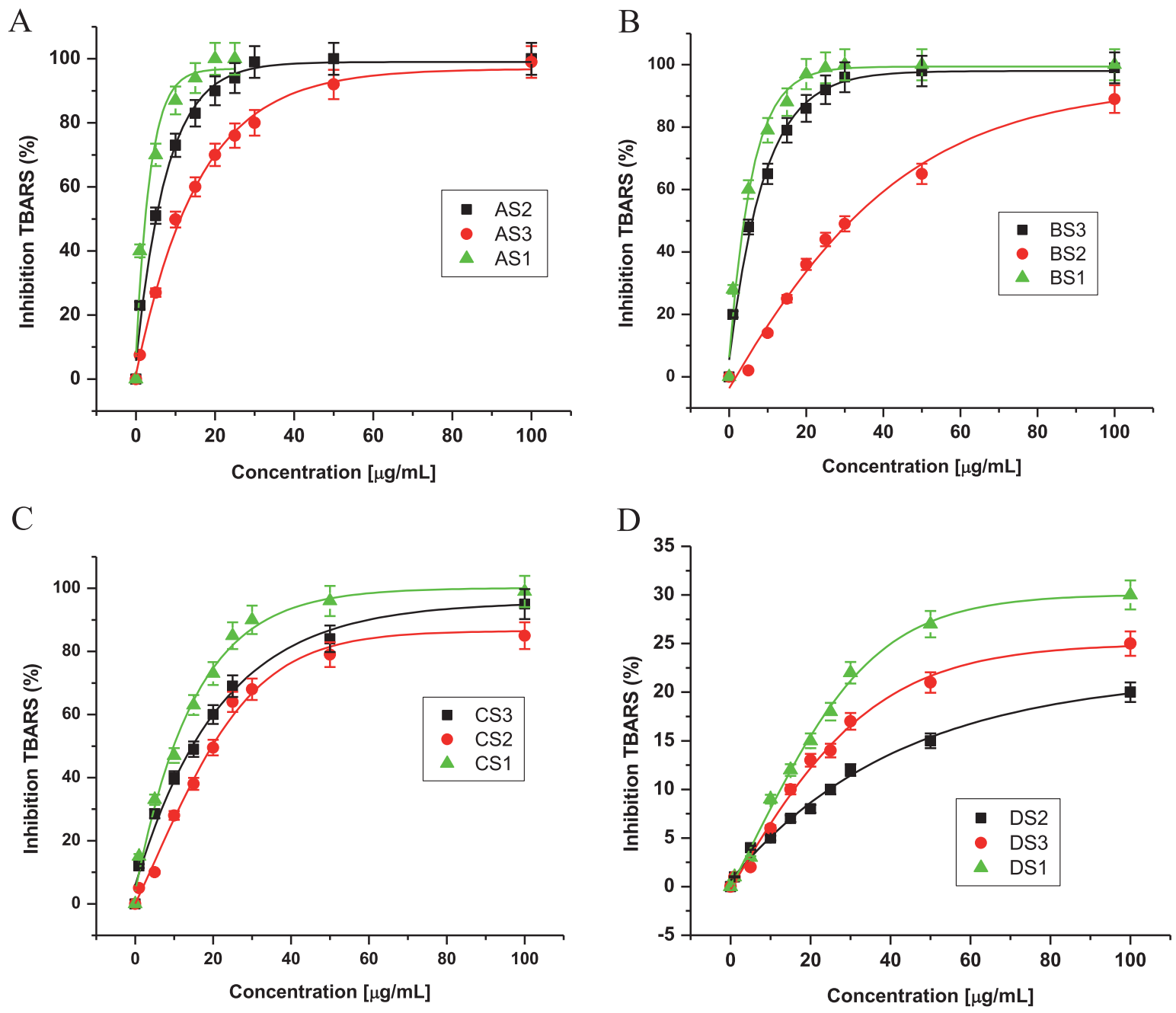

Fig. 3. Effects of extracts from three varieties of Maqui berry Aristotelia chilensis on the production of TBARS in rat brain homogenate. (A). AS1, AS2, AS3, (B). BS1, BS2, BS3, (C) CS1, CS2, CS3, (D) DS1, DS2, DS3. For explanation of the extracts and partitions, see Fig. 1.

[66]. Halliwell $[1,67]$ has defined antioxidants as substances that, when present at low concentrations comparing with an oxidizable compound (e.g. DNA, protein, lipid, or carbohydrate), delay or prevent oxidative damage due to the presence of ROS. These ROS can undergo a redox reaction with phenolics, such that oxidant activity is inhibited in a concentration-dependent manner. In the presence of low concentrations of phenolics or other antioxidants, the breaking of chain reactions is the predominant mechanism [68], and the presence of phenolics has been suggested to be the most active substances from natural sources [44]. Thus, total phenolic content was measured in each extract. Extracts AS1 and BS1 which had the greatest antioxidant activities (Tables 1 and 2), had significantly greater phenolic contents than other extracts. These findings correlate well with methanol and acetone extracts AS1 and BS1 having greatest activities against DPPH and TBARS. Because AS1 and BS1 had one of the greatest activities against DPPH and TBARS formations, it is possible that this fraction has the active components. 


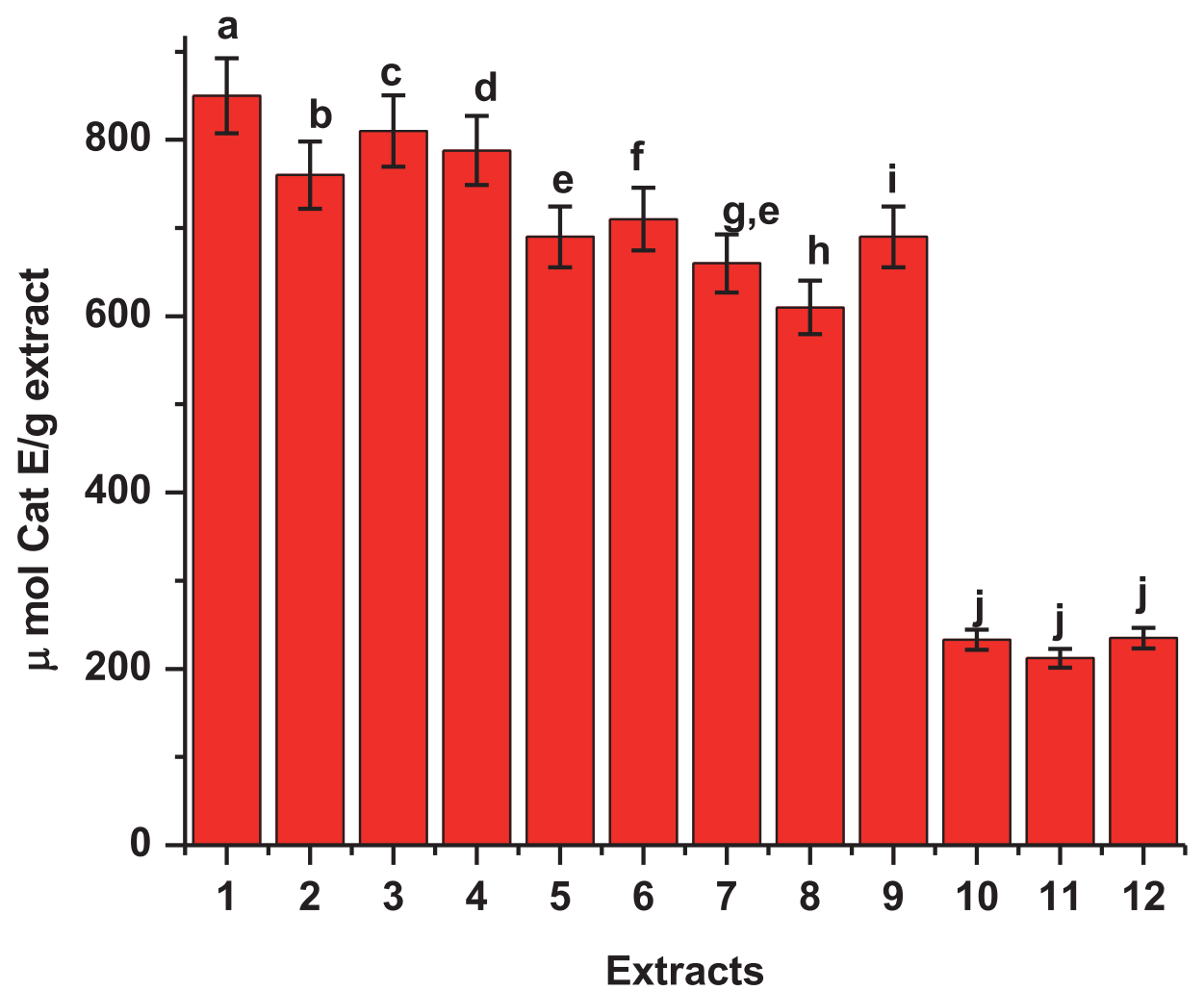

Fig. 4. Total phenolic content of extracts from fruits of three varieties of Maqui berry Aristotelia chilensis. Expressed as $\mu$ mol of catequin equivalents per $\mathrm{g}$ of extract. For explanation of the extracts and partitions, see Fig. 1. 1: AS1, 2: AS2, 3: AS3, 4: BS1, 5: BS2, 6: BS3, 7: CS1, 8: CS2, 9: CS3, 10: DS1, 11: DS2, 12: DS3. Values are the mean \pm SE of three replicates $(n=3)$; different letters show significant differences treatments in comparison to control at $P<0.01$, using the Tukey test.

The capacity for a chemical species to scavenge peroxyl radicals generated by spontaneous decomposition of AAPH was estimated by Trolox equivalents, using the ORAC assay [47]. A wide variety of different phytochemicals from edible plants, purified or as an extract or fraction, have been found to be active in this assay, including alkaloids, coumarins, flavonoids, phenylpropanoids, terpenoids and phenolic acids [51, 45]. Among the extracts assayed, the values were found to be in the range of 11569.9 to $30790.9 \mu \mathrm{mol} \mathrm{TE} / \mathrm{g}$ extract for ORAC and from 6682.4 to $21200.1 \mu \mathrm{mol} \mathrm{Cat} \mathrm{E/g} \mathrm{extract} \mathrm{for} \mathrm{the} \mathrm{FRAP} \mathrm{assay,} \mathrm{respectively} \mathrm{(Table} \mathrm{2).} \mathrm{As} \mathrm{with} \mathrm{our} \mathrm{earlier}$ measurements [20], acetone and methanol extracts had the highest activity in both assays, AS1, AS3, BS1 and AS2 had values of 30790.9, 28480.9, 27663.4 and 26288.7 for ORAC and BS1, AS1, BS3 and AS3 had values of 21200.1, 19973.9, 19939.9 and 19199.4 for FRAP assays, respectively. In a general scope, acetone extract B showed a very good potency with values between 19760.9 to $27663.4 \mu \mathrm{mol} \mathrm{TE} / \mathrm{g}$ for ORAC and between 18100.9 to $21200.1 \mu \mathrm{mol}$ Cat E/g for FRAP assay, respectively. The other assayed extract (C) showed values of intermediate potency in the ORAC and FRAP assays without significantly difference $(P<0.05)$, respectively (Table 2).

At this point only extracts A and B showed substantial activity. Interestingly, extracts from wild varieties having more phenolic content and they were the fractions had higher activities in both assays (ORAC and FRAP). One possible explanation for the low values obtained for $\mathrm{C}$ samples, is that for these samples, the reaction of the ferric-TPTZ complex was only partially completed within the 10 min reaction period which agrees with the ORAC assay, [20]. 
Antioxidant activities have a direct relationship with the phenolic content of the extracts and fractions. Same as DPPH and TBARS assays, extracts A and B were most active in both ORAC and FRAP assays. These results correlated very well with total polyphenolic composition of all extracts and partitions.

The phenolic characterization $[23,94,95]$ suggests that the different phytochemicals in the active samples, mainly anthocyanins, organic acids (cinnamic derivatives) and flavonoids, may be involved in the antioxidant mechanism of action and the ORAC method gives us a direct measure of hydrophilic chain-breaking antioxidant capacity against peroxyl radical of our extracts (Fig. 4). Thus, the highest ORAC numbers of our extracts and fractions show an excellent antioxidant potential (Table 2). Besides, the ORAC numbers of extracts showed a very high correlation with polyphenol content $(\mathrm{R}>0.95)$ (data not show), the same level of correlation was observed between the FRAP numbers and phenolic composition of the extracts and fractions (Table 2). In the case of the extract A and B, there is a similar level of correlation $(\mathrm{R}>0.98)$ between FRAP numbers and its polyphenolic content. A complete phytochemical analysis of MB extracts was reported [20, 21, 23, 94, 95].

The polar extracts from fruits of MB significantly reduced the increased MDA values. These results suggest that $\mathrm{MB}$ is important for the reduction of $\mathrm{I} / \mathrm{R}$-induced damage [21]. The mechanism by which MB extract prevents heart injury is probably by blocking the free radical formation after ischemia-reperfusion even if $I / R$ is a complex phenomenon that involves other mechanisms such as intracellular calcium overloading and loss of membrane phospholipids [21], which are not assayed in the current study.

Because heart ischemia-reperfusion causes free radical production and maqui berry polyphenols (MBP) are effective free radical scavengers [21], that study was designed to test the hypothesis that MBP will block free radical formation, thus preventing injury. Indeed, MBP and one of its major polyphenolic components, anthocyanins, significantly reduced liver injury after ischemia-reperfusion [21]. Protection by MBP and anthocyanins was associated with decreased free radical formation [20]. Besides, MBP prevented NF- $\kappa$ B activation and proinflammatory cytokine formation [20,21]. Consistent with these observations, a previous report showed that green tea polyphenols blunted endotoxin that induced NF- $\kappa B$ activation and TNF- $\kappa$ production [69].

Based on these data, there is possibility that MBP inhibits NF- $\kappa B$ activation by nonantioxidant mechanism. Nevertheless, a variety of structurally diverse antioxidants and antioxidative enzymes has been shown previously to inhibit NF- $\mathrm{B}$ mediated cytokine production stimulated by endotoxin, consistent with prooxidant stimulation

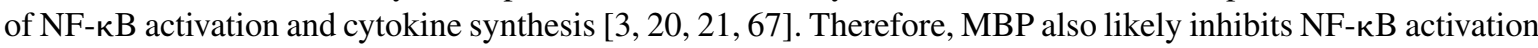
by scavenging free radicals. Taken together, other studies demonstrate that MBP effectively decreases oxidative stress $[14,20,21,23]$ and thus it might be useful in disease status where colon injury plays a role, there is no report from epidemiological or clinical studies regarding this issue. Further studies will be needed to determine whether the antioxidant effect of MBP increases or decreases the risk for sepsis and colonic and intestinal polyps.

\subsection{Anti-inflammation}

\subsubsection{NO production and COX-2}

In previous studies of NO production inhibitory activity by MBP, the most polar extracts from MB exhibited excellent inhibitory activity against ROS and a strong anti-inflammatory activity against TPA-induced inflammation in mouse ear edema model in a dose dependent manner $[20,23,24]$. These data are consistent with inhibition of the expression of the enzyme COX-2 and iNOS enzyme because it is known that the production of nitrite is closely linked to the expression of COX-2. These effects have been reported previously for MBP, flavonoids and anthocyanins [20, 25, 70-74, 97].

Cyclooxygenase (COX) is the rate-limiting enzyme in PG synthesis and exists as two isoforms: constitutive (COX-1) and inducible (COX-2) [75]. Thus, like iNOS, COX-2 is an important enzyme that mediates inflammatory processes. Multiple lines of compelling evidence support that COX-2 plays a role in the development of tumors [76]. Thus, aberrant or excessive expression of iNOS and COX-2 are implicated in inflammatory disorders and the pathogenesis of cancer. In previous work [20,21], it was reported that the most polar extracts ( $\mathrm{MeOH}$ and acetone) suppressed the LPS-induced COX-2 expression in a dose-dependent manner [20, 21, 23]. 


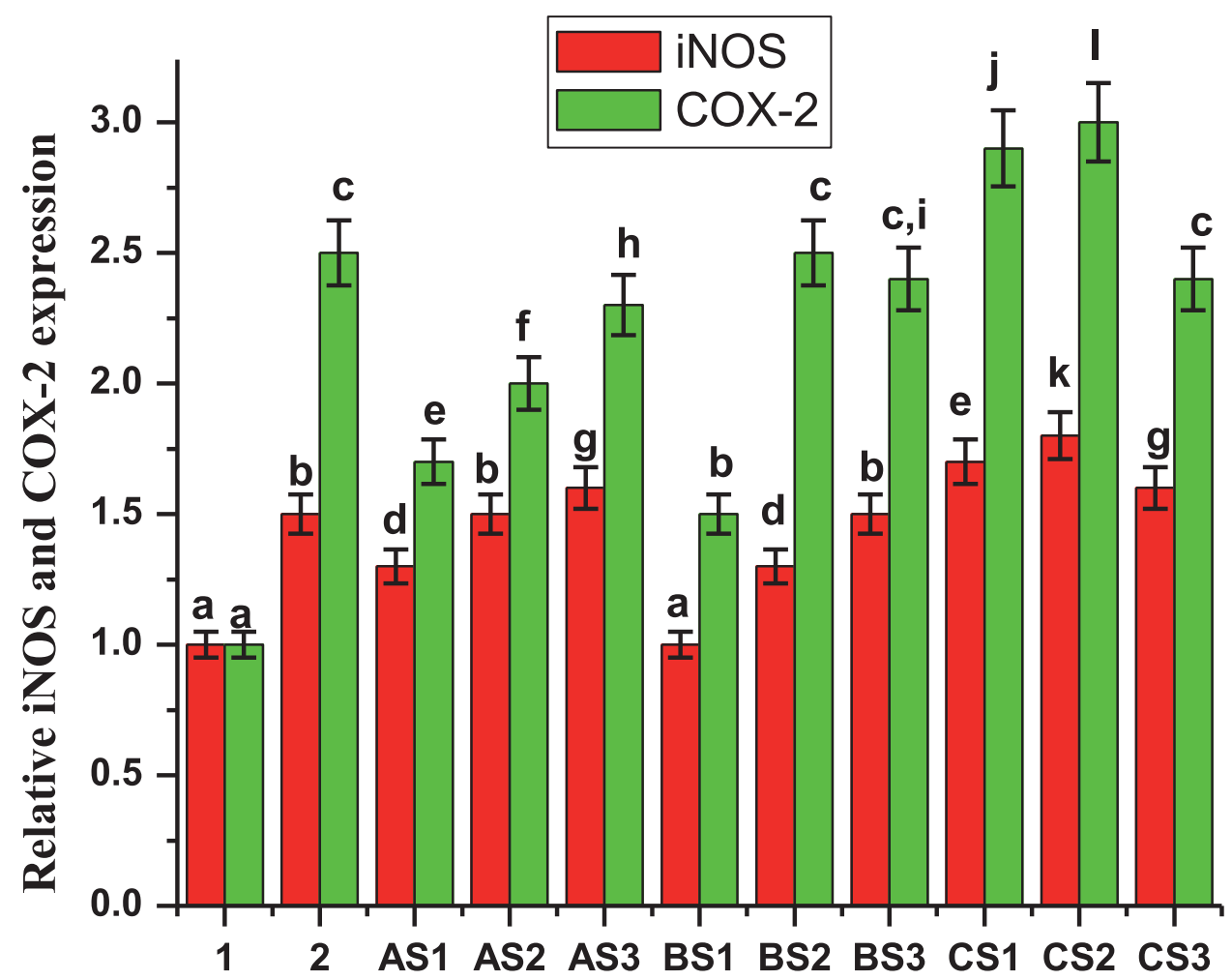

Fig. 5. iNOS / COX 2 inhibition. Effects of $10.0 \mu \mathrm{g} / \mathrm{mL}$ of extracts from three varieties of Maqui berry Aristotelia chilensis on iNOS and COX-2 protein expression in LPS-stimulated RAW 264.7 macrophages. 1: control. 2: LPS. Explanation of the extracts (AS1, AS2, AS3, BS1, BS2, BS3, CS1, CS2 and CS3) and partitions, see Fig. 1. The results of extract D (residues) were not graphed because of their very low effects. Values are the mean $\pm \mathrm{SE}$ of three replicates $(n=3)$; different letters show significant differences treatments in comparison to control at $P<0.01$, using the Tukey test.

Pro-inflammatory genes transcribed by NF-кB include IL-1 $\beta$, IL-6, tumor necrosis factor- $\alpha$ (TNF- $\alpha$ ). IL-1 $\beta$ and IL-6 induce the expression of COX-2 and iNOS, promoting the action of prostaglandin E2 (PGE2) and of nitric oxide (NO), respectively. COX-2 provides many inflammatory processes and causes various carcinomas, and a constitutive overexpression of COX-2 produces a high level of resistance to apoptosis [77-79].

Blackberry, blueberry, cranberry, grape, raspberry, elderberry, pomegranate, strawberry, and black raspberry extracts have been shown to inhibit NF- $\mathrm{B}$ activation [70-73, 80-82].

The inhibition of NF- $\kappa$ B by black raspberries results from the phosphorylation of ІкB- $\alpha$ and from the inhibition of the PI3K/Akt pathway [83]. Most berry extracts inhibit LPS-induced NF-кB activation and the subsequent production of COX-2 and of pro-inflammatory prostaglandins [70, 73, 80, 81]. The inhibition of the transcriptional activity of NF-кB by cranberry extracts has been shown to lead to the inhibition of COX-2 gene expression and to a decrease in the production of the pro-inflammatory cytokines IL-1 $\beta$, IL-6, IL-8, and TNF- $\alpha$ [84-86].

New extracts from diverse varieties of MB are assessed and results confirmed the findings reported in Cespedes et al., 2017 [20]. Figure 5 showed the inhibition of iNOS and COX-2 protein expression for the most active extracts, confirming the inhibitory activity of extracts A and B. Noteworthily, the only difference shown in this study is the amount of total phenols measured in the three extracts evaluated. This showed that the wild variety "Buli" had a greater amount of phenols and this correlated very well with the level of activity shown by extract 


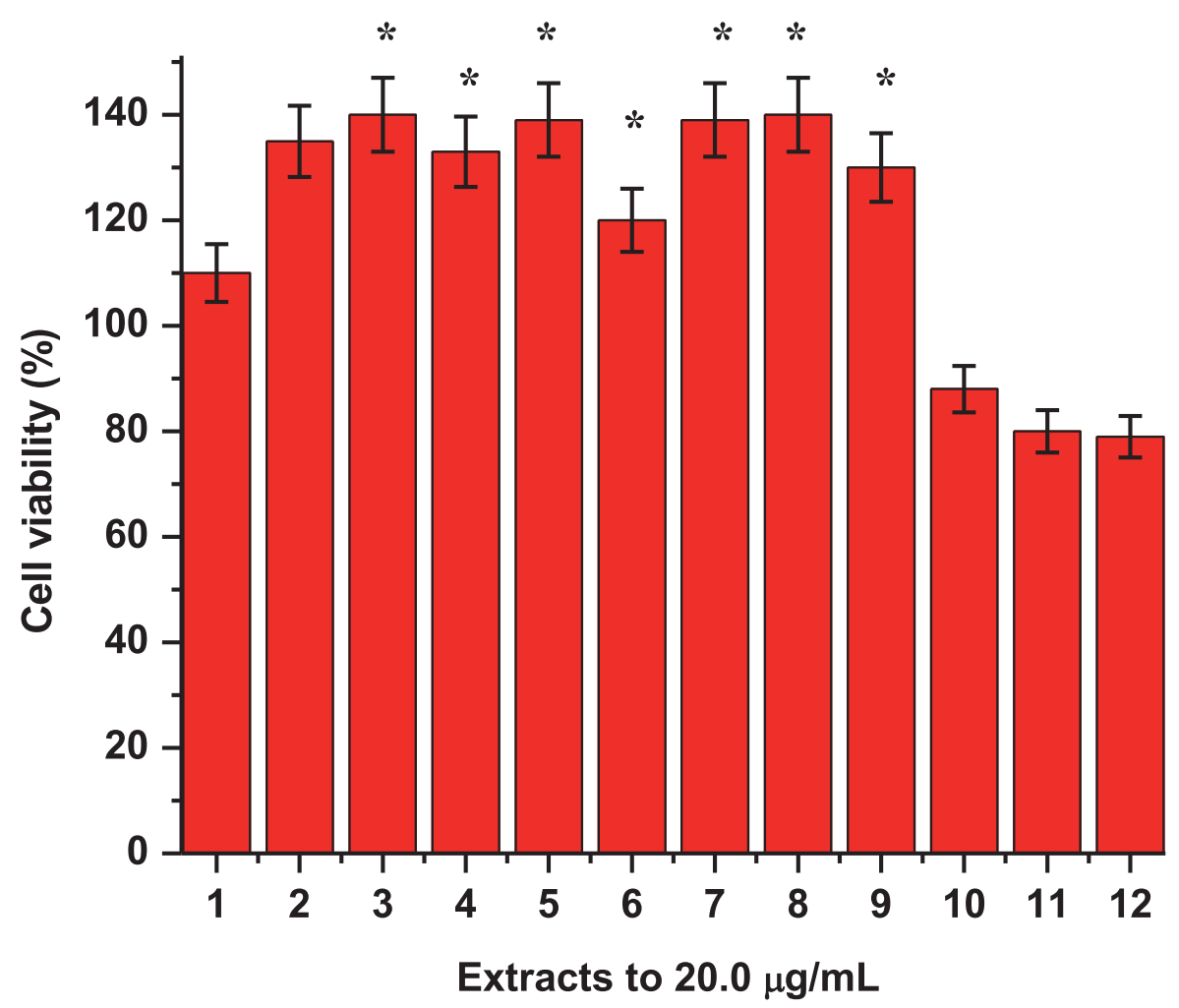

Fig. 6. Effects of extracts from three varieties of Maqui berry Aristotelia chilensis on viability of macrophages RAW 264.7. 1. Control, 2: LPS, 3: AS1, 4: AS2, 5: AS3, 6: BS1, 7: BS2, 8: BS3, 9: CS1, 10: CS2, 11: CS3, 12: DS1. Data are expressed as the mean \pm SE at least of three independent experiments. For explanation of the extracts and partitions, see Fig. $1 . * P<0.05$ represent a significant difference compared with values obtained from control group.

A and B of this variety. On the other hand, the cytotoxicity of samples was evaluated throughout the viability of macrophages RAW-264.7 treated with LPS with and without the assayed samples (Fig. 6).

\subsubsection{Inhibition of growth of colon cancer cells}

The effects of growth inhibition of HT-29 and Caco-2 colon cancer cells showed moderated variability according to extracts and doses. The SRB and MTT assays showed the effects of MBP treatments on the proliferation of HT-29 and Caco-2 colon cancer cells.

Cells were incubated with anthocyanin rich extract from MBP at concentrations of 1.0, 5.0, 10.0, 15.0, 30.0, and $50 \mu \mathrm{g} / \mathrm{mL}$ for 48 hours. MB extract appeared to be cytotoxic to HT-29 and Caco- 2 cells above $50 \mu \mathrm{g} / \mathrm{mL}$. The inhibition levels were over $100 \%$ when concentrations were greater than $50 \mu \mathrm{g} / \mathrm{mL}$. The overall observed growth inhibition of HT-29 and Caco-2 cells when treated with MB AS1, AS3, BS1 and BS3 extracts at concentrations of 30,50 and $100 \mu \mathrm{g} / \mathrm{ml}$ were between 70 to $100 \%$ (Fig. 7 (A-C), and the $\mathrm{IC}_{50}$ in Table 3).

When cells were incubated in medium with domestic variety "Coihueco", the extract B with anthocyanin rich extract, in contrast to the wild varieties' extracts, this showed low HT-29 and Caco-2 cell inhibition at same concentrations evaluated. However, the methanol extract of this variety showed greater than $50 \%$ inhibition at concentrations higher than $50 \mu \mathrm{g} / \mathrm{ml}$. The overall observed growth inhibitions of HT-29 and Caco-2 cells when treated with A and B extracts at concentrations greater than $50 \mu \mathrm{g} / \mathrm{ml}$ were up to $90 \%$. These data suggest that extract B rich in anthocyanins, flavonoids and organic acids when used to treat HT-29 and Caco-2 cells at 

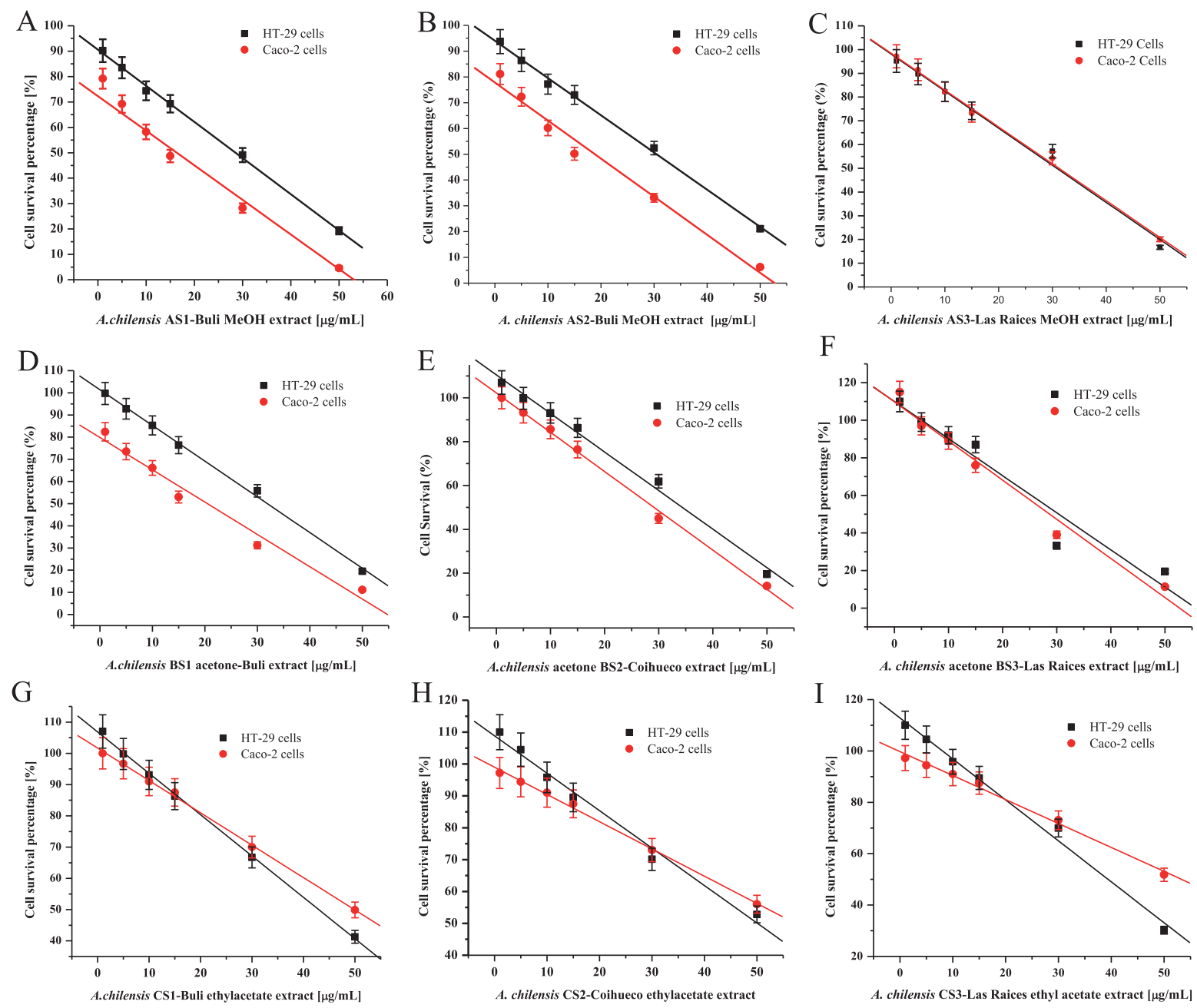

Fig. 7. Cytotoxic effects of extracts from three varieties of Maqui berry Aristotelia chilensis on HT-29 and Caco-2 cells. (A) AS1, (B) AS2, (C) AS3, (D) BS1, (E) BS2, (F) BS3, (G) CS1, (H) CS2, (I) CS3. For explanation of the extracts and partitions, see Fig. 1. Each point is the average of three independent experiments. Values are the mean $\pm \mathrm{SE}$ of three replicates, $(n=3)$.

concentrations $50 \mu \mathrm{g} / \mathrm{ml}$ and below have a greater chemopreventive effect than those of $\mathrm{C}$ partitions and residue D (Fig. 7).

Our data suggests that the observed anti-proliferative activity may be associated with anthocyanin contents because the treatment of anthocyanin rich extracts B inhibited the normal HT-29 and Caco- 2 cell growth pattern. The proliferation of HT-29 and Caco- 2 cells was inhibited by the anthocyanin rich extract Bs in a dose dependent manner (Fig. 7).

The extracts used in this study contained different glycosylation and acylation patterns. MB contains anthocyanins, flavonoids, organic acid groups (cinnamic, gallic, ferulic, caffeic, among other) [23, 94, 95]. Organic aliphatic acids donate electrons to the anthocyanin chemical structure and cause a bathochromic shift and a hyperchromic effect $[87,88]$. Acylation also contributes to the stabilization of the anthocyanin via intermolecular interaction [89]. Aliphatic acid acylation is an important structural character to consider when studying the chemopreventive effects of anthocyanins [98]. 
Table 3

$\mathrm{IC}_{50}$ values of cell growth inhibitory activity (cytotoxicity) on HT-29 and Caco- 2 cells by three varieties of Maqui berry Aristotelia chilensis

\begin{tabular}{lcc}
\hline Sample $^{\mathrm{a}}$ & HT-29C $(\%)$ & Caco-2 (\%) \\
\hline AS1 & $28.50 \pm 2.81 \mathrm{a}$ & $15.96 \pm 2.50$ \\
AS2 & $30.15 \pm 2.62$ & $18.90 \pm 2.51$ \\
AS3 & $30.65 \pm 2.86$ & $30.2 \pm 2.71$ \\
BS1 & $31.64 \pm 2.71$ & $19.95 \pm 2.65$ \\
BS2 & $34.30 \pm 3.05$ & $28.87 \pm 2.25$ \\
BS3 & $30.67 \pm 1.65$ & $28.50 \pm 1.95$ \\
CS1 & $42.69 \pm 2.01$ & $50.16 \pm 2.49$ \\
CS2 & $49.65 \pm 2.64$ & $55.97 \pm 2.89$ \\
CS3 & $39.27 \pm 2.86$ & $52.70 \pm 2.59$ \\
\hline
\end{tabular}

${ }^{a}$ Extracts A (Methanol/water (1:1)), B (Acetone partition), C (Ethyl Acetate partition); from three varieties of Maqui berry Aristotelia chilensis. For details, see Fig. 1, and Material and Methods. Data for Extract D was not shown due to its very low effects.

Each value is the average of three independent experiments.

The results of this study showed that the growth of HT-29 and Caco-2 colon cancer cells were significantly suppressed when treated with anthocyanins, organic acids and flavonoids of MBP extracts (A and B). The growth inhibition of HT-29 and Caco-2 cells was greater than 100\% when treated with MBP extracts at concentrations greater than $50.0 \mu \mathrm{g} / \mathrm{ml}$, which indicates that the extract exhibited a cytotoxic effect, the $\mathrm{IC}_{50}$ values shows that effects (Table 3). The ethyl acetate (C) extract was a moderate/weak inhibitor; however, it did not necessarily exhibit a cytotoxic effect. These findings have also been confirmed by the research of Pan et al. [33-35, 90-92], where polyphenolic extracts rich in anthocyanins from Black Raspberries were found to exhibit a dose dependent inhibitory effect on the growth of colonic cancer cells. The results suggest that an extract enriched in anthocyanin/flavonoid/organic acids can maintain or increase the cell growth inhibitory effect to levels comparable to other extracts contain anthocyanin (Fig. 4) [33-35, 70, 80, 81, 90-93].

Anthocyanin-rich MBP extracts contain cinnamic acid (sinapic, ferulic, caffeic, p-coumaric, etc). Cinnamic acids are known for their aromatic ring chemical structure. Previous research suggests that anthocyanin acylation with cinnamic acids may negatively correlate to the inhibition of HT-29 colon cancer cell proliferation [32].

Preceding analysis of the extracts have shown the occurrence of non-acylated anthocyanins $[23,94,95]$. Thus, HT-29 colon cancer cell growth inhibition was increased when treated with sample B rich in anthocyanins at a concentration of $50 \mu \mathrm{g} / \mathrm{ml}$. These findings suggest that organic acids in the extracts have an important impact on the chemoprotective effect of anthocyanins. The saponification of acylated anthocyanins considerably increases chemoprotection [96]; suggesting that both acylation and aglycone have a major impact on the chemoprevention of anthocyanins. More specifically, a previous study compared the inhibition of HT-29 cell proliferation of mono-glucosylated and try-glycosylated pelargonidin and cyanidin derivatives [32]. This study found that more sugars attached to the molecule caused decreased growth inhibition in the HT-29 cell line. Anthocyanins in MB have different glycosylation patterns $[23,94,95]$. The results of this work strongly support the hypothesis that the presence of sugar substitutions significantly decrease anthocyanins' chemoprotective properties. Comparing to our anthocyanin sources and their chemical structures, it is also possible and likely that the position of the glycosylation has an impact on the ability of the extracts to inhibit HT-29 colon cancer cell proliferation.

\subsubsection{Concluding remarks}

These extracts of MB exhibited substantial potency in scavenging DPPH-radical and inhibiting lipid peroxidation. Two of the four extracts from MB, A and B, showed potency in scavenging against DPPH-radicals, as 
well as a strong inhibitory effect against lipid peroxidation. The antioxidant activities, total phenolic content and ORAC and FRAP assays were all correlated. Acetone partition B showed the activity that suggests the phenolic compounds are probably low or medium molecular weights, with relative high polarity. Phytochemical analysis of these extract, partitions and fractions are in progress, and it is expected to identify chemical structures of bioactive components that may have a role in human health maintenance.

Many cellular components are sensitive to oxidative damage, caused by the presence of nitrogen or oxygen reactive species, including a myriad of different free radicals. Rat brain homogenates, rich in lipids such as polyunsaturated fatty acids that can undergo peroxidation. Our findings showed that the extract A and acetone partition B of MB containing antioxidants that can inhibit lipid peroxidation and they have a high phenolic content. The relationship between total phenolics with ORAC and FRAP values in all extracts and fractions was similar with those found in other methanol and ethyl acetate plant extracts from different known fruits and vegetables such as prunes, raisins, blueberries, spinach and Broccoli [70, 73, 80, 81].

The results of this research provided evidence that chemical structure plays an important role in HT-29 and Caco-2 colon cancer cell growth inhibition. The presence of organic (cinnamic/ferulic) acids in MB extracts increased or maintained their chemoprotective abilities. Anthocyanins, cinnamic acids and flavonoids exhibited different chemoprotective effects depending on the aglycone and glycosylation patterns.

Triglycosylated anthocyanins had a negative correlation in HT-29 colon cancer inhibition, as well as their structural position. The in vitro activity of anthocyanins may be relevant to in vivo effects because when ingested anthocyanins are in direct contact with the epithelial cell layer of the colon. However, further research is needed to better understand the impact of glycosylation on anthocyanin for chemoprevention.

Other study reported that Maqui berry juice inhibits the expression of COX-2 [97]. However, apparently the way is not going to inhibit NF-кB but through the NFAT [86]. So heart, kidney, blood vessels, the cardiovascular system are protected as a whole. This confirmed the previous findings from our group that concentrated extracts protected the heart from oxidative stress $[20,21]$.

These findings warrant the research of Maqui Berry concentrates for preventive use against colon cancer. The metabolomic analysis can be used to elucidate the chemical structure of anthocyanins that occur in each variety [98].

\section{Acknowledgments}

This work was supported in part by internal grant from Direccion de Investigacion, Universidad del Bio Bio, Chillan, Chile (Grant \# 091909-1/R); in part by grants FONDECYT-2920018, FIA PYT-2015-029 and in part by grants from UC-MEXUS-CONACYT (\#2005-2010-02). The authors thanks to Roberto Rodriguez (Facultad de Ciencias Naturales y Oceanograficas, Universidad de Concepcion, Concepcion, Chile) and Prof David S. Seigler, curator Herbarium of University of Illinois at Urbana-Champaign, USA, for botanical identification of the plant. We thank Ma. Teresa Ramirez-Apan, and Antonio Nieto for technical assistance: Chemistry Institute, Ana Ma. Garcia-Bores: UBIPRO FES-Iztacala, UNAM, Mexico D.F., Mexico. Anne Murray (ESPM, UC, Berkeley); CLC and IK acknowledge to Seed Funds Program of Conicyt-Chile and UC-Berkeley "2013 UC Berkeley-Chile Seed Grants”, grant (\# 2013-02): A New Connection: Potential Cancer Treatment Agents.

\section{References}

[1] Halliwell B, Aruoma OI. DNA damage by oxygen derived species. Its mechanism and measurement in mammalian systems. FEBS Letters. 1991;281:9-19.

[2] Prior RL, Hoang H, Gu L, Wu X, Bacchiocca M, Howard L, Hampsch-Woodill M, Huang D, Ou B, Jacob R. Assays for hydrophilic and lipophilic antioxidant capacity (oxygen radical absorbance capacity (ORACFL)) of plasma and other biological and food samples. Journal of Agricultural and Food Chemistry. 2003;51:3273-9. 
[3] Roberts WG, Gordon MH, Walker AF. Effects of enhanced consumption of fruit and vegetables on plasma antioxidants status and oxidative resistance of LDL in smokers supplemented with fish oil. European Journal of Clinical Nutrition. 2003;57:1303-10.

[4] Fernandes E, Costa D, Toste SA, Lima JLFC, Reis S. In vitro scavenging activity for reactive oxygen and nitrogen species by nonsteroidal anti-inflammatory indole, pyrrole and oxazole derivative drugs. Free Radical Biology and Medicine. 2004;37:1985-905.

[5] Taruscio TG, Barney DL, Exon J. Content and profile of flavonoids and phenolic acid compounds in conjunction with the antioxidant capacity for a variety of northwest Vaccinium Berries. Journal of Agricultural and Food Chemistry. 2004;52:3169-76.

[6] Prior RL, Wu X, Schaich K. Standardized Methods for the Determination of Antioxidant Capacity and Phenolics in Foods and Dietary Supplements. Journal of Agricultural and Food Chemistry. 2005;53:4290-302.

[7] Prior RL, Sintara M, Chang T. Multi-radical (ORACMR5) antioxidant capacity of selected berries and effects of food processing. Journal of Berry Research. 2016;6:159-73.

[8] Tumbas V, Čanadanović-Brunet J, Gille L, Dilas S, Ćetković G. Superoxide anion radical scavenging activity of bilberry (Vaccinium myrtillus L.). Journal of Berry Research. 2010;1:13-23.

[9] Schinella GR, Tournier HA, Prieto JM, Mordugovich de Buschiazzo P, Rios JL. Antioxidant activity of anti-inflammatory plants extracts. Life Sciences. 2002;70:1023-33.

[10] Yan X, Murphy BT, Hammond GB, Vinson JA, Neto CC. Antioxidant Activities and Antitumor Screening of Extracts from Cranberry Fruit (Vaccinium macrocarpon). Journal of Agricultural and Food Chemistry. 2002;50:5844-49.

[11] Hertog MGL, Feskens EJM, Hollman PCH, Katan B, Kromhout D. Dietary antioxidant flavonoids and risk of coronary heart disease: The Zutphen elderly study. Lancet. 1993;342:1007.

[12] Stoner GD, Mukhtar H. Polyphenols as cancer chemopreventive agents. Journal of Cell Biochemistry Suppl. 1995;22:169-80.

[13] Teng H, Lin Q, Li K, Yuan B, Song H, Peng H, Yi L, Wei M-Ch, Yang Y-Ch, Battino M, Cespedes-Acuna CL, Chen L, Xiao J. Hepatoprotective effects of raspberry (Rubus coreanus Miq.) seed oil and its major constituents. Food Chemical Toxicology. 2017;110:418-24.

[14] Pool-Zobel BL, Bub A, Schroder N, Rechkemmer G. Anthocyanins are potent antioxidants in model systems but do not reduce endogenous oxidative DNA damage in human colon cells. European Journal Nutrition. 1999;38:227-34.

[15] Smith MAL, Marley KA, Seigler DS, Singletary KW, Meline B. Bioactive properties of wild blueberry fruits. Journal of Food Sciences. 2000;65:352-6.

[16] Cespedes CL, Jakupovic J, Silva M, Watson W. Indole alkaloids from Aristotelia chilensis. Phytochemistry. 1990;29:1354-6.

[17] Cespedes CL, Jakupovic J, Silva M, Tsichritzis F. A quinoline alkaloid from Aristotelia chilensis. Phytochemistry. 1993;34:881-2.

[18] Silva M, Bittner M, Cespedes C, Jakupovic J. The Alkaloids of the genus Aristotelia. Aristotelia chilensis (Mol) Stuntz. Boletin Sociedad Chilena de Quimica. 1997;42:39-47.

[19] Watson W, Nagl A, Silva M, Cespedes C, Jakupovic J. A New Indole Alkaloid from Aristotelia chilensis. Journal Acta Crystallographica C. 1989;C45:1322-4.

[20] Cespedes CL, Pavon N, Dominguez M, Alarcon J, Balbontin C, Kubo I, El-Hafidi M, Avila JG. The chilean superfruit black-berry Aristotelia chilensis (Elaeocarpaceae), Maqui as mediator in inflammation-associated Disorders. Food and Chemical Toxicology. 108;2017:438-50.

[21] Cespedes CL, El-Hafidi M, Pavon N, Alarcon J. Antioxidant and cardioprotective activities of phenolic extracts from fruits of Chilean Blackberry Aristotelia chilensis (Elaeocarpaceae), Maqui. Food Chemistry. 2008;107:820-9.

[22] Cespedes CL, Alarcon J, Valdez M, Paredes-Lopez O. Antioxidant Activity of an Unusual 3-Hydroxyindole Derivative Isolated from Fruits of Aristotelia chilensis (Mol) Stuntz. Zeitschrift fur Naturforschung C. 2009;64c(9/10):759-62.

[23] Cespedes CL, Valdez M, Avila JG, El-Hafidi M, Alarcon J, Paredes-Lopez O. Phytochemical Profile and the Antioxidant Activity of Chilean Wild Black Berry Fruits, Aristotelia chilensis (Mol) Stuntz (Elaeocarpaceae). Food Chemistry. 2010;119(3):886-95.

[24] Cespedes CL, Alarcon J, Avila JG, Nieto A. Anti-Inflammatory Activity of Aristotelia chilensis Mol. (Stuntz) (Elaeocarpaceae). Boletin Latinoamericano y del Caribe de Plantas Medicinales y Aromaticas. 2010;9(2):127-35.

[25] Cespedes CL, Alarcon J, Avila JG, El-Hafidi M. Anti-inflammatory, antioedema and gastroprotective activities of Aristotelia chilensis extracts, part 2. Boletin Latinoamericano y del Caribe de Plantas Medicinales y Aromaticas. 2010;9(6):432-9.

[26] Fuentes O, Cespedes CL, Sepulveda R. Aristotelia chilensis, rutin and quercetin amielorates acute vascular endothelial dysfunction in rat thoracic aorta exposed to oxidative stress. Boletin Latinoamericano y del Caribe de Plantas Medicinales y Aromaticas. 2015;14(1):11-20.

[27] Cespedes CL, Balbontin C, Avila JG, Dominguez M, Alarcon J, Paz C, Burgos V, Ortiz L, Peñaloza-Castro I, Seigler DS, Kubo I. Inhibition on cholinesterase and tyrosinase by alkaloids and phenolics from Aristotelia chilensis leaves. Food and Chemical Toxicology. 2017;109(Part 2):984-95.

[28] Bhakuni DS, Bittner M, Marticorena C, Silva M, Weldt F, Hoeneisen M, Hartwell JL. Screening of Chilean plant for anticancer activity. Journal of Natural Products. 1976;39:225-43. 
[29] Zuñiga G, Tapia A, Arenas A, Contreras RA, Zuñiga-Libano G. Phytochemistry and biological properties of Aristotelia chilensis a Chilean blackberry: A review. Phytochemistry Review. 2017;16:1081-94.

[30] Fredes C, Yousef GG, Robert P, Grace MH, Lila MA, Gomez M, Gebauer M, Montenegro G. Anthocyanin profiling of wild maqui berries (Aristotelia chilensis [Mol.] Stuntz) from different geographical regions in Chile. Journal of Science Food Agricultural. 2014;94:2639-48.

[31] Liu Z, Fan Y, Wang Y, Han C, Pan Y, Huang H, Ye Y, Luo L, Yin Z. Dipyrithione inhibits lipopolysaccharide-induced iNOS and COX-2 up-regulation in macrophages and protects against endotoxic shock in mice. FEBS Lett. 2008;582:1643-50.

[32] Jing P, Bomser JA, Schwartz SJ, He J, Magnuson BA, Giusti MM. Structure-function relationships of anthocyanins from various anthocyanin-rich extracts on the inhibition of colon cancer cell growth. Journal of Agricultural and Food Chemistry. 2008;56:9391-8.

[33] Pan P, Skaer CW, Wang HT, Stirdivant SM, Young MR, Oshima K, Stoner GD, Lechner JF, Huang YW, Wang LS. Black raspberries suppress colonic adenoma development in ApcMin/+ mice: Relation to metabolite profiles. Carcinogenesis. 2015;36(10):1245-53.

[34] Pan P, Skaer C, Yu J, Zhao H, Ren H, Oshima K, Wang LS. Berries and other natural products in the pancreatic cancer chemoprevention in human clinical trials. Journal Berry Research. 2017;7(3):147-61.

[35] Pan P, Lam V, Salzman N, Huang YW, Yu J, Zhang J, Wang LS. Black Raspberries and Their Anthocyanin and Fiber Fractions Alter the Composition and Diversity of Gut Microbiota in F-344 Rats. Nutrition and Cancer. 2017;69(6):943-51.

[36] Zhao C, Giusti MM, Malik M, Moyer MP, Magnuson BA. Effects of Commercial Anthocyanin-Rich Extracts on Colonic Cancer and Nontumorigenic Colonic Cell Growth. Journal of Agricultural and Food Chemistry. 2004;52(20):6122-28.

[37] Lala G, Malik M, Zhao C, He J, Kwon Y, Giusti MM, Magnuson BA. Anthocyanin-rich extracts inhibit multiple biomarkers of colon cancer in rats. Nutrition and Cancer. 2006;54(1):84-93.

[38] Aoki H, Wada K, Kuzo N, Ogawa Y, Koda T. Inhibitory effect of anthocyanin colors on mutagenicity induced by 2-amino-1-methyl6-phenylimidazo[4,5-b]pyridine (PhIP). Foods and Food Ingredients Journal of Japan. 2004;209:240-6.

[39] Hagiwara A, Miyashita K, Nakanishi T, Sano M, Tamano S, Kadata T, Koda T, Nakamura M, Imaida K, Ito N, Shirai T. Pronounced inhibition by a natural anthocyanin, purple corn color, of 2-amino-1-methyl-6-phenylimidazo[4,5-b]pyridine (PhIP)-associated colorectal carcinogenesis in male F344 rats pretreated with 1,2-dimethylhydrazine. Cancer Letters. 2001;171:17-25.

[40] Harris GK, Gupta A, Nines RG, Kresty LA, Habib SG, Frankel WL, LaPerle K, Gallaher DD, Schwartz SJ, Stoner GD. Effects of lyophilized black raspberries on azoymethane-induced colon cancer and 8-hydroy-2-deoxyguanosine levels in the Fisher 344 rat. Nutritional Cancer. 2001;40:125-33.

[41] Kang SY, Seeram NP, Nair MG, Bourquin LD. Induction of apoptosis in cancer cells by Bilberry (Vaccinium myrtillus) and the anthocyanins. Journal of Agricultural and Food Chemistry. 2003;51:68-75.

[42] Bors W, Saran M, Eltsner EF. Modern Methods Plant Analysis. New Series, Acad. Press N.Y. 1992;13:277.

[43] Cuendet M, Hostettmann K, Potterat O, Dyatmiko W. Iridoid glucosides with free radical scavenging properties from Fagraea blumei. Helvetica Chimica Acta. 1997;80:1144-52.

[44] Rice-Evans C. Measurement of total antioxidant activity as a marker of antioxidant status in vivo: Procedures and limitations. Free Radical Research. 2000;33:559-66.

[45] Rice-Evans C, Miller NJ, Bolwell PG, Bramley PM, Pridham JB. The relative antioxidant activities of plant-derived polyphenolic flavonoids. Free Radical Research. 1995;22:375-83.

[46] Ou B, Hampsch-Woodill M, Prior RL. Development and validation of an improved oxygen radical absorbance capacity assay using fluorescein as the fluorescent probe. Journal of Agricultural and Food Chemistry. 2001;49:4619-26.

[47] Cao G, Prior RL. Measurement of oxygen radical absorbance capacity in biological samples. Methods Enzymology. 1999;299:50-62.

[48] Benzie IFF, Strain JJ. Ferric reducing/antioxidant power assay: Direct measure of total antioxidant activity of biological fluids and modified version for simultaneous measurement of total antioxidant power and ascorbic acid concentration. Methods Enzymology. 1999;299:15-27.

[49] Singleton VL, Rossi JA. Colorimetry of total phenolics with phosphomolybdic acid reagents. American Journal of Enology and Viticulture. 1965; 16:144-53.

[50] Singleton VL, Orthofer R, Lamuela-Raventos RM. Analysis of total phenols an d other oxidation substrates and antioxidants by means of Folin-Ciocalteu reagent. Methods Enzymology. 1999;299:152-78.

[51] Ng TB, Liu F, Wang ZT. Antioxidative activity of natural products from plants. Life Sciences. 2000;66:709-23.

[52] Rossato JI, Ketzer LA, Centuriao FB, Silva SJ, Lüdtke DS, Zeni G, Braga AL, Rubin MA, Rocha BT. Antioxidant properties of new chalcogenides against lipid peroxidation in rat brain. Neurochemistry Research. 2002;27:297-303.

[53] Lowry OH, Rosebroug NJ, Farr AL, Randall RJ. Protein measurement with the Folin-phenol reagent. Journal of Biological Chemistry. 1951;193:265-75.

[54] Ohkawa H, Ohishi N, Yagi K. Assay for lipid peroxides in animal tissues by thiobarbituric acid reaction. Analytical Biochemistry 1979; $95: 351-8$. 
[55] Esterbauer H, Cheeseman KH. Determination of aldehydic lipid peroxidation products. Methods Enzymology. 1990;186:407-21.

[56] Chen L-G, Yang L-L, Wang Ch-Ch. Anti-inflammatory activity of mangostins from Garcinia mangostana. Food and Chemical Toxicology. 2008;46:688-93.

[57] Chen K-F, Chen H-L, Tai W-T, Feng W-Ch, Hsu Ch-H, Chen P-J, Cheng A-L. Activation of Phosphatidylinositol 3-Kinase/Akt Signaling Pathway Mediates Acquired Resistance to Sorafenib in Hepatocellular Carcinoma Cells. Journal of Pharmacology and Experimental Therapeutics. 2011;337(1):155-61.

[58] Fajardo AR, Lopes LC, Caleare AO, Britta EA, Nakamura CV, Rubira AF, Muniz EC. Silver sulfadiazine loaded chitosan/chondroitin sulfate films for a potential wound dressing application. Materials Science and Engineering C. 2013;33:588-95.

[59] Skehan PH, Storeng R, Scudiero D, Monks A, McMahon J, Vistica D, Warren JT, Bokesch H, Kenney S, Boyd MR. New Colorimetric Cytotoxicity Assay for Anticancer-Drug Screening. Journal of the National Cancer Institute. 1990;82(13):1107-12.

[60] Ehlenfeldt MK, Prior RL. Oxygen Radical Absorbance Capacity (ORAC) and Phenolic and Anthocyanin Concentrations in Fruit and Leaf Tissues of Highbush Blueberry. Journal of Agricultural and Food Chemistry. 2001;49:2222-7.

[61] Diplock AT, Charleux JL, Crozier-Willi G, Kok FJ, Rice-Evans C, Robefroid M, Stahl W, Viña-Ribes J. Functional food science and defense against reactive oxidative species. British Journal of Nutrition. 1998;80(suppl. 1):S77-S112.

[62] Ko FN, Cheng ZJ, Lin CN, Teng CM. Scavenger and antioxidant properties of prenylflavones isolated from Artocarpus heterophyllus. Free Radical Biology and Medicine. 1998;25:160-8.

[63] Makris DP, Rossiter JT. Comparison of quercetin and non-orthohydroxy flavonol as antioxidants by competing in vitro oxidation reactions. Journal of Agricultural and Food Chemistry. 2001;49:3370-7.

[64] Lo KM, Cheung PCK. Antioxidant activity of extracts from the fruiting bodies of Agrocybe aegerita var. alba. Food Chemistry. 2005;89(4):533-9.

[65] Rice-Evans CA, Miller NJ, Paganga G. Antioxidant properties of phenolic compounds. Trends in Plant Science. 1997;2:152-9.

[66] Veglioglu YS, Mazza G, Gao L, Oomah BD. Antioxidant activity and total phenolics in selected fruits, vegetables, and grain products. Journal of Agricultural and Food Chemistry. 1998;46:4113-7.

[67] Halliwell B, Gutteridge JMC. Role of free radicals and catalytic metal ions in human disease. Methods Enzymology. 1990;186:1-85.

[68] Pokorny J, Davidek J, Tran HC, Valentova H, Matejicek J, Dlaskova Z. Reactions of oxidized lipids with protein. Part 15. Mechanism of lipoprotein formation from interactions of oxidized ethyl linoleate with egg albumin. Nahrung. 1988;32:343-50.

[69] Yang F, de Villiers WJ, McClain CJ, Varilek GW. Green tea polyphenols block endotoxin-induced tumor necrosis factor-production and lethality in a murine model. Journal of Nutrition. 1998;128(12):2334-40.

[70] Folmer F, Basavaraju U, Jaspars M, Hold G, El-Omar E, Dicato M, Diederich M. Anticancer effects of bioactive berry compounds. Phytochemistry Reviews. 2014;13:295-322.

[71] Chiang A, Wu H, Yeh H, Chu C, Lin H, Lee W. Antioxidant effects of black rice extract through the induction of superoxide dismutase and catalase activities. Lipids. 2006;41:797-803.

[72] Wang Q, Xia M, Liu Ch, Guo H, Ye Q, Hu Y, Zhang Y, Hou M, Zhu H, Ma J, Ling W. Cyanidin-3-O- $\beta$-glucoside inhibits iNOS and COX-2 expression by inducing liver X receptor alpha activation in THP-1 macrophages. Life Sciences. 2008;83:176-184.

[73] Kruger MJ, Davies N, Myburgh KH, Lecour S. Proanthocyanidins, anthocyanins and cardiovascular diseases. Food Research International. 2014;59:41-52.

[74] Nabavi SF, Braidy N, Habtemariam S, Orhan IE, Daglia M, Manayi S, Gortzi O, Nabavi SM. Neuroprotective effects of chrysin: From chemistry to medicine. Neurochemistry International. 2015; 90:224-31.

[75] Chang YG, Wu MSH, Lin JT, Sheu BSH, Muta T, Inoue H, Chen CHCH. Induction of Cyclooxygenase-2 Overexpression in Human Gastric Epithelial Cells by Helicobacter pylori Involves TLR2/TLR9 and c-Src-Dependent Nuclear Factor-кB Activation. Molecular Pharmacology. 2004;66:1465-77.

[76] MacMicking J, Xie QW, Nathan C. Nitric oxide and macrophage function. Annual Review of Immunology. 1997;15:323-50.

[77] Hou DX, Yanagita T, Uto T, Masuzaki S, Fujii M. Anthocyanidins inhibit cyclooxygenase-2 expression in LPS-evoked macrophages: structure-activity relationship and molecular mechanisms involved. Biochemistry Pharmacology. 2005;70:417-25.

[78] Hsu A, Bray TM, Ho E. Anti-inflammatory activity of soy and tea in prostate cancer prevention. Experimental Biology and Medicine. 2010;235:659-67.

[79] Krysan K, Dalwadi H, Sharma S, Pold M, Dubinett S. Cyclooxygenase 2-dependent expression of survivin is critical for apoptosis resistance in non-small cell lung cancer. Cancer Research. 2004;64:6359-62.

[80] Wang L-Sh, Stoner GD. Anthocyanins and their role in cancer prevention. Cancer Letters. 2008;269(2):281-90.

[81] Zikri NN, Riedl KM, Wang L-SH, Lechner JF, Schwartz SJ, Stoner GD. Black Raspberry Components Inhibit Proliferation, Induce Apoptosis and Modulate Gene Expression in Rat Esophageal Epithelial Cells. Nutrition and Cancer. 2009;61(6):816-26.

[82] Zhang Y, Seeram NP, Lee R, Feng L, Heber D. Isolation and identification of strawberry phenolics with antioxidant and human cancer cell antiproliferative properties. Journal of Agricultural and Food Chemistry. 2008;56:670-5. 
[83] Lu HT, Li JX, Zhang DY, Stoner GD, Huang CS. Molecular mechanisms involved in chemoprevention of black raspberry extracts: From transcription factors to their target genes. Nutrition and Cancer. 2006;54:69-78.

[84] Neto CC. Cranberry and blueberry: Evidence for protective effects against cancer and vascular diseases. Molecular Nutrition and Food Research. 2007a;51:652-64.

[85] Neto CC. Cranberry and its phytochemicals: A review of in vitro anticancer studies. Journal Nutrition. 2007b;137:186S-193S.

[86] Kirkby NS, Chan MB, Zaiss AK, Garcia-Vaze E, Jiao J, Berglund LM, Verdu EF, Ahmetaj-Shala B, Wallace JL, Herschman HR, Gomez MF, Mitchell JA. Systematic study of constitutive cyclooxygenase-2 expression: Role of NF-кB and NFAT transcriptional pathways. Proc Nat Acad Sciences. 2016;113:2434-9.

[87] von Elbe, J. H., and Schwartz, S. J. Colorants, In Food Chemistry, O. R. Fennema, ed. (New York: Marcel Dekker). 1996.

[88] Giusti MM, Rodriguez-Saona LE, Wrolstad RE. Molar absorptivity and color characteristics of acylated and non-acylated pelargonidinbased anthocyanins. Journal of Agricultural and Food Chemistry. 1999;47:4631-7.

[89] Giusti MM, Wrolstad RE. Acylated Anthocyanins from edible sources and their applications in food systems. Biochemical Engineering Journal. 2003;14:217-25.

[90] Pan P, Skaer CW, Wang HT, Oshima K, Huang YW, Yu J, Zhang J, Yearsley MM, Agle KA, Drobyski WR, Chen X, Wang LS. Loss of free fatty acid receptor 2 enhances colonic adenoma development and reduces the chemopreventive effects of black raspberries in ApcMin/+ mice. Carcinogenesis. 2017;38(1):86-93.

[91] Pan P, Skaer CW, Wang HT, Kreiser MA, Stirdivant SM, Oshima K, Huang YW, Young MR, Wang LS. Systemic Metabolite Changes in Wild-type C57BL/6 Mice Fed Black Raspberries. Nutrition and Cancer. 2017;69(2):299-306.

[92] Pan P, Kang S, Wang Y, Liu K, Oshima K, Huang YW, Zhang J, Yearsley M, Yu J, Wang LS. Black Raspberries Enhance Natural Killer Cell Infiltration into the Colon and Suppress the Progression of Colorectal Cancer. Frontiers Immunology. $2017 ; 8: 997$.

[93] Ferrari D, Speciale A, Cristani MT, Fratantonio D, Molonia MS, Ranaldi G, Saija A, Cimino F. Cyanidin-3-O-glucoside inhibits NF-kB signalling in intestinal epithelial cells exposed to TNF-a and exerts protective effects via Nrf2 pathway activation. Toxicology Letters. 2016;264:51-8.

[94] Brauch JE, Kroner M, Schweiggert RM, Carle R. Studies into the Stability of 3-O-Glycosylated and 3,5-O-Diglycosylated Anthocyanins in Differently Purified Liquid and Dried Maqui (Aristotelia chilensis (Mol.) Stuntz) Preparations during Storage and Thermal Treatment. Journal of Agricultural and Food Chemistry. 2015;63(39):8705-14.

[95] Brauch JE, Reuter L, Conrad J, Vogel H, Schweiggert RM, Carle R. Characterization of anthocyanins in novel Chilean maqui berry clones by HPLC-DAD-ESI/MSn and NMR-spectroscopy. Journal of Food Composition and Analysis. 2017;58:16-22.

[96] Yoshimoto M, Okuno Sh, Yamaguchi M, Yamakawa O. Antimutagenicity of deacylated anthocyanins in purple-fleshed sweetpotato. Biosciences Biotechnology and Biochemistry. 2001;65(7):1652-5.

[97] Ojeda J, Jara E, Molina L, Parada F, Burgos RA, Hidalgo MA, Hancke JL. Effects of Aristotelia chilensis berry juice on cyclooxygenase 2 expression, NF-кB, NFAT, ERK1/2 and PI3K/Akt activation in colon cancer cells. Boletín Latinoamericano y del Caribe de Plantas Medicinales y Aromáticas. 2011;10(6):543-52.

[98] Lin B-W, Gong CH-CH, Song H-F, Cui Y-Y. Effects of anthocyanins on the prevention and treatment of cancer. British Journal of Pharmacology. 2017;174:1226-43. 